\title{
Axial incision: The key to understand submarine canyon evolution (in the western Gulf of Lion)
}

\author{
J. Baztan ${ }^{a, b, ~}{ }^{*}$, S. Bernéb ${ }^{\text {, J.-L } \text { Olivet }^{b}, \text { M. Rabineau }}{ }^{a}$, D. Aslanian ${ }^{b}$, M. Gaudin ${ }^{\text {b, c }}$, \\ J.-P. Réhault ${ }^{a}$ and M. Canals ${ }^{d}$
}

\author{
${ }^{a}$ U. Bretagne Occidentale, UMR 6538, IUEM Domaines Océaniques, Place Nicolas Copernic, Plouzané, F-29280 \\ Plouzané, France \\ ${ }^{\mathrm{b}}$ IFREMER, DRO/GM, BP 70, Plouzané F-29280, France \\ c U. Bordeaux I, Dépt, Géologie et Océanographie, UMR 5805 EPOC, Av. des Facultés, Talence F-33405, France \\ ${ }^{\mathrm{d}} \mathrm{U}$. Barcelona, GRC Geociencies Marines, Barcelona S-08028, France
}

*: Corresponding author: Juan Baztan Tel.: (33) 2982242 39; Fax: (33) 2982245 49; e-mail:jbaztan@ifremer.fr

\begin{abstract}
:
A detailed morphological analysis of the outer shelf and continental slope of the Western Gulf of Lion is presented, based on swath bathymetry data together with sub-bottom profiles and high resolution seismic reflection profiles. These data reveal two main erosive features, of very different dimensions: the axial incision and the canyon's major valley. The height of axial incisions' flanks with respect to the canyon deepest point (the thalweg) ranges from 40 to $150 \mathrm{~m}$. It creates a small axial erosive path within the canyon's major valley, which is typically bounded by flanks of more than $700 \mathrm{~m}$ in height.

We interpret the axial incision observed in the sea floor as the imprint of turbidity currents that eroded the floor of canyons during phases of connection to rivers (hyperpycnal turbidity current). Such currents are most likely to have formed during the Last Glacial Maximum (LGM) as both proximity of the shoreline (due to the lowstand of sea level) and high detrital sediment supply (due to glacial abrasion upstream) increased the flow of sediments delivered to the canyon heads. Fossil axial incisions, observed in seismic lines, are related to equivalent conditions.

The axial incision, however, has a key influence on canyon evolution as it triggers mass wasting of different sizes that affect the canyon's major valley (head and flanks). We interpret the geometry of the canyon's major valley as the result of recurrent activity of axial incisions. These periods of activity occurred during low sea levels at glacial maxima and show a cyclicity of 100,000 years for the last 400,000 years.
\end{abstract}

Keywords: Submarine canyon; Axial incision; Gulf of Lion 


\begin{abstract}
A detailed morphological analysis of the outer shelf and continental slope of the Western Gulf of Lion is presented, based on swath bathymetry data together with sub-bottom profiles and high resolution seismic reflection profiles. These data reveal two main erosive features, of very different dimensions: the axial incision and the canyon's major valley. The height of axial incisions' flanks with respect to the canyon deepest point (the thalweg) ranges from 40 to $150 \mathrm{~m}$. It creates a small axial erosive path within the canyon's major valley, which is typically bounded by flanks of more than 700 meters in height.
\end{abstract}

We interpret the axial incision observed in the sea floor as the imprint of turbidity currents that eroded the floor of canyons during phases of connection to rivers (hyperpycnal turbidity current). Such currents are most likely to have formed during the Last Glacial Maximum (LGM) as both proximity of the shoreline (due to the lowstand of sea level) and high detrital sediment supply (due to glacial abrasion upstream) increased the flow of sediments delivered to the canyon heads. Fossil axial incisions, observed in seismic lines, are related to equivalent conditions.

The axial incision, however, has a key influence on canyon evolution as it triggers mass wasting of different sizes that affect the canyon's major valley (head and flanks). We interpret the geometry of the canyon's major valley as the result of recurrent activity of axial incisions. These periods of activity occurred during low sea levels at glacial maxima and show a cyclicity of 100 000 years for the last 400000 years. 


\section{Introduction}

Following the pioneering work on submarine canyons (Dana, 1863), several descriptions and hypothesis to explain the formation and evolution of canyons have been published. Shepard (1936) suggested that the canyons off New England could not have been excavated during one single period of erosion because of the height of canyon walls; he suggested that canyons might be the result of a succession of emersion, erosion and filling. Daly (1936) and Kuenen (1938) discovered the erosive power of marine turbidity currents. Daly (1936) was the first to suggest that submarine canyons are eroded by turbidity currents. Early studies in submarine canyons were restricted to canyon heads and it was Veatch and Smith (1939) that discovered the seaward extension of submarine canyons across the continental slope. In the Gulf of Lion, studies conducted in the Lacaze-Duthiers canyon (Bourcart et al., 1948) and Aude canyon (Bourcart, 1960; Duplaix \& Olivet, 1971) showed that they were filled and partially reexcavated to form a new canyon, not as deep as the previous one. Aloïsi et al. (1975) observed that periods of maximum sea-level falls were associated with excavation at the shelf edge and rejuvenation of submarine canyons. Twichell and Roberts (1982) and Farre et al. (1983) proposed that canyons are eroded by turbidity currents but also by retrogressive mass wasting of the slope. Based on ideas from Daly (1936) and Farre et al. (1983) a model for head-ward erosion of submarine canyons induced by downslope eroding sediment flows was proposed by Pratson for the New Jersey continental slope (Pratson et al., 1994; Pratson and Coakley 1996) and confirmed by the work of Mountain et al. (1996).

The presence of an axial incision was described in Wilmington and Carteret canyons on the East Coast of the United States (Slater, 1981) and the Gully Canyon in Nova Scotia (Stanley 
and Silverberg, 1969). Along Mediterranean margins, axial incisions were observed within Peñiscola canyon (O'Connell et al., 1987), Foix, Marta and Benicarlo canyons (Alonso et al., 1991) and the regional collector of all canyons on the Ebro Margin, the Valencia Channel (Canals et al., 2000).

However, the origin of submarine canyons remains a matter of speculation. In addition, the axial incisions in submarine canyons, the processes at their origin, and the effect of incision on canyon evolution have not yet been studied.

Within the Gulf of Lion, the best studied submarine canyon-channel system is the Petit Rhône. It feeds the Rhône deep-sea fan to the east of our study area (e.g. Bellaiche et al., 1983; Droz et al., 1985; Droz, 1991; Kenyon et al., 1995; Bellaiche and Mart, 1995; Torres et al., 1995; Torres et al., 1997; Droz et al., 2001). Due to relatively unprecise mapping techniques, the morphology of the western Gulf of Lion submarine canyons was comparatively poorly known (Bourcart, 1960; Glangeaud et al., 1968; Got \& Stanley, 1974; Canals, 1985). A swath bathymetry survey led to a detailed map of this area (Berné \& Loubrieu, 1999; Berné et al., 2002), that is used as a base for this study.

This paper focuses on the radially distributed canyons that converge into the roughly N-S oriented Sète Canyon (Fig. 1). It proposes a mechanism for the origin and the key role of the axial incision in canyon evolution and it establishes the relation with sea level changes. 


\section{Data}

The bathymetric data set for the slope was collected during the CALMAR-97 cruise (Berné \& Loubrieu, 1999) (using a SIMRAD EM12-Dual multibeam echosounder on board R/V L'Atalante in 1997), and completed by cruises BASAR2 (SIMRAD EM950 multibeam echosounder on board R/V L'Europe in 1995), CALMAR-99 (SIMRAD EM1000 multibeam echosounder on board R/V L'Europe in 1999) and STRATAFORM (SIMRAD EM300 multibeam echosounder on board R/V Le Suroit in 2002). The bathymetric data were acquired and post-processed with IFREMER's CARAIBES software. The bathymetric data set on the shelf comes from sounding charts from the French Hydrographic Service (SHOM), that were interpreted and digitized at the 1:20.000 scale (Berné et al., 2002).

The seismic data come from the same cruises. They include GI-gun seismic profiles shot at 8 knots with a 6-channel streamer, sub-bottom profiles $(3.5 \mathrm{kHz}$ with $150 \mathrm{~m}$ maximum penetration) and Sparker data. These seismic data were digitally recorded with a DELPH system and post-processed with IFREMER's SITHERE software. Multichannel (24 channels) profiles from the MARION cruise (on R/V Le Suroît in 2000) complete this data set, profiles crossing canyons have been depth migrated with IFREMER's SISBISE software to correct for pull-down effect. 


\section{General setting}

The Gulf of Lion is a prograding margin mainly fed by the terrigenous input from the Rhône river that builds the Rhône deep sea fan seawards (e.g., Droz and Bellaiche, 1985). Hérault, Aude and Têt rivers are secondary sediment sources located in the western part of the gulf (Fig. 1). During sea-level highstands, similar as today, the main depocenter is near the coast and builds a high-stand wedge (Monaco, 1971). The remaining fraction is transferred offshore by nepheloid layers (Aloïsi et al., 1979). The sediments are also distributed along the coast by littoral drift (Aloïsi et al., 1979; Monaco et al., 1987) and on the outer shelf by the LiguroProvençal geostrophic current that flows along the margin in a counter-clockwise direction (Millot, 1990). During glacial periods, river outlets were close to the shelf edge and favoured a large accumulation of sediments on the outer shelf, the continental slope, rise and abyssal plain (Got and Stanley, 1974; Canals, 1985; Torres 1995; Berné et al., 1998a; Droz et al., 2001).

Recent results based on core data, seismic stratigraphy and stratigraphic simulation (Rabineau, 2001) provide the outlines of depositional patterns, in the middle and outer shelf. They show that sedimentary sequences record $100 \quad 000$ years glacioeustatic (interglacial/glacial) cycles for the last 540000 years. Each cycle shows a major discontinuity that is a regional regressive erosional surface named D-70, D-60, D-50, D-40 and D-30 developed during lowering of sea level and lowest stand that are correlated to marine isotopic stages 2, 6, 8, 10 and 12 respectively (Rabineau, 2001 and Rabineau this issue). 
Three physiographic provinces characterize the study area: the outer continental shelf (with a $0.1^{\circ}$ slope) ; the continental slope $\left(1.5^{\circ}\right)$ and the rise $\left(0.9^{\circ}\right)$ (Fig. 1). The continental slope is dissected by six major submarine canyons (Cap Creus, Lacaze-Duthiers, Pruvôt, Bourcart (also named Aude), Hérault and Sète canyons from the $\mathrm{W}$ to the $\mathrm{E}$ ), which develop from the shelf break to the rise between 90 and 2000 m water depth (Fig. 1). The major branches of these canyons have been numbered in a clockwise direction (Fig. 2). 


\section{Results}

\section{1- Morphological characteristics}

Two main erosive features, of very different dimensions, can be observed: the axial incision

and the canyon's major valley with high flanks (Fig. 3). The morphometric characteristics of both the canyons' major valleys and their axial incisions (azimuth, west flank height, east flank height, flanks average height, average width, width/height ratio,....) are summarized in Table 1 and presented in Fig. 3.

Based on the bathymetric and seismic data, we distinguish three types of present day geometry for the canyon's major valley : infilled canyons, incised canyons and empty canyons.

\section{(i) Infilled canyons:}

This type of canyon displays partial or total sediment infill. The branches HRC1, HRC4, STC1 and STC2 of the Hérault and Sète canyons correspond to this type (Fig.2 ). HRC1 is an about $5 \mathrm{~km}$-wide slight depression, nearly completely filled and no axial incision is visible (Fig. 4). This canyon Seismic profiles (Fig. 4B) show that the canyon head had fossil flanks higher than $200 \mathrm{~m}$ and was filled afterwards.

\section{(ii) Incised canyons}

Such canyons are partially infilled and subsequently incised by axial erosion. Branches HRC2 and HRC3 of the Hérault canyon, branch BCC2 of the Boucart canyon, and parts of the 
Lacaze-Duthiers and Cap Creus canyons are examples of this type (Figs. 2, 4A, 4C, 5A, 6A, 6B, 7A and 7B).

In the about $2 \mathrm{~km}$ wide branches HRC2 and HRC3, the canyon flanks height reach 200-250 m in the head (Fig. 4A) with, locally, a $20^{\circ}$ flank slope. In both branches, canyon heads reach the shelf at a depth around $110 \mathrm{~m}$. In the upper part of the canyon heads, a complex system of minor gullies converge towards the $40 \mathrm{~m}$-deep and $400 \mathrm{~m}$-wide axial incision at $3.7 \mathrm{~km}$ from the head and $300 \mathrm{~m}$ water depth (Fig. 4A). Further seaward, the two incisions converge at around $500 \mathrm{~m}$ water depth in a single axial incision, $700 \mathrm{~m}$ wide and $40 \mathrm{~m}$ height on average (Fig. 4). The axial incision disappears where the Hérault canyon joins the Sète canyon at about $1.800 \mathrm{~m}$ of water depth (about $60 \mathrm{~km}$ from the canyon head), forming a $400 \mathrm{~m}$ hanging valley (Figs. 1 and 2).

The branch BCC2 of the Bourcart canyon (Fig. 5) is a 5-6 km large canyon. Its canyon's major valley reaches $890 \mathrm{~m}$ (western flank) and $820 \mathrm{~m}$ (eastern flank) in height with flank slopes of $20^{\circ}$ and $10^{\circ}$ respectively. Its head intersects the shelf edge at $110 \mathrm{~m}$ water depth. This axial incision is well developed with a mean depth of $50 \mathrm{~m}$ and an average width of $300 \mathrm{~m}$. It starts with a meandering morphology between $110 \mathrm{~m}$ and $450 \mathrm{~m}$ water depth and a height of $60 \mathrm{~m}$. Its path straightens and its height decreases between $450 \mathrm{~m}$ and $1400 \mathrm{~m}$ water depth where the canyon is captured by the Lacaze-Duthiers canyon (58 $\mathrm{km}$ from the canyon head) (Fig. 2). On the eastern flank of the canyon, semi-circular slump scars can be observed (Fig. 5). 
Lacaze-Duthiers canyon reaches a depth of $700 \mathrm{~m}$ with a good symmetry between the two flanks; their slopes reach $20^{\circ}$. In this $8 \mathrm{~km}$ wide canyon (on average), the axial incision is well defined between 500 and $1700 \mathrm{~m}$ water depth (Figs. 2 and 6). The incision shows an average width of $1800 \mathrm{~m}$, an average height of $150 \mathrm{~m}$ and an average thalweg azimuth of $\mathrm{N}$ $124^{\circ}$. The axial incision height decreases from $260 \mathrm{~m}$ (15 km from the head) to $80 \mathrm{~m}(70 \mathrm{~km}$ from the head), with a mean value of $150 \mathrm{~m}$.

The height of Cap Creus canyon reaches $500 \mathrm{~m}$ (eastern flank) and $800 \mathrm{~m}$ (western flank). The flank slopes reach $15^{\circ}$ and are erosive. The axial incision develops between 640 and 1700 m water depth (Figs. 2 and 7A). In the upper and middle parts of the canyon (between 120 and $640 \mathrm{~m}$ water depth) the incision is not visible (Figs. 2 and 7A). At $20 \mathrm{~km}$ from the canyon head, the incision is about $100 \mathrm{~m}$ high and decreases to $50 \mathrm{~m}, 50 \mathrm{~km}$ seaward (Fig. 7C). The morphology suggests that major slides affected the flanks and that the erosion has erased the imprint of the axial incision in its upper course (Fig. 7). The axial incision is no more visible at depths greater than $1700 \mathrm{~m}$ water depth where the canyon is affected by listric faults. These faults, expressed in the bathymetry (Fig. 2), are rooted into the underlying Messinian salt (Dos Reis, 2001; Dos Reis , this issue).

\section{(iii) Empty canyons}

This type of canyon is characterized by abrupt flanks without any visible infilling deposits. It is only represented by two canyon branches among all the studied canyons: the LacazeDuthiers and the Cap Creus canyons, in the upper part of their course. Further downstream, these empty canyons pass into incised canyons at about $15 \mathrm{~km}$ from the canyon head (Figs. 6A, 6C, 7A and 7C). The Lacaze-Duthiers canyon head, with a flank height of more than 
$400 \mathrm{~m}$ and a width of $4 \mathrm{~km}$, illustrates this longitudinal transition. At the shelf edge they reach and erode the seaward termination of the Last Glacial Maximum shoreface sands (Berné et al., 1998b). This erosion retrogrades up to the $100 \mathrm{~m}$ contour line and induces a longitudinal profile without any break in slope in the upper part (compare longitudinal profiles of Cap Creus and Lacaze-Duthiers with profiles of Bourcart and Hérault canyons).

\section{2- Stratigraphic correlation}

We have extended downslope the interpretation of major discontinuities identified on the outer shelf in order to relate canyon history to Quaternary glacial cycles. The main discontinuities that we tracked are D-70, D-60, D-50 and D-40, that correspond to Marine Isotope Stages (MIS) 2, 6, 8 and 10 respectively (Rabineau, 2001 and this issue). We will examine successively very high resolution and high resolution multi-channel seismic data.

Seismic profiles across the upper course of the Bourcart canyon show that a large incision existed during MIS 6 (Fig. 8). Between MIS 6 and MIS 2, a large volume of sediment accumulated, especially in the canyon head, where it reaches up to $300 \mathrm{~ms}$. The canyon has been nearly completely filled afterwards then re-incised by the last eroding episode that creates the axial incision visible on the sea floor. The second section (Fig. 8B) is

located seaward (Fig. 5A) and shows the same sequence but with a smaller volume of deposited sediment between D-60 and D-70.

Multichannel depth-migrated seismic profiles illustrate the downslope evolution of the main discontinuities : D-60 related to the glacial maxima and previously described in the very 
high resolution seismic data, and underlying D-50 and D-40 (Figs. 9 and 10). The seaward evolution of these discontinuities are observed along the Aude-Hérault interfluve, where the sedimentation is not disturbed by the presence of the canyon (Fig. 9). In multichannel profile 6020 (Fig. 10-A, same location than profile sparker-5089 in Fig. 8B) we can see the evolution of discontinuities (D70-LGM, D-60, D-50 and D-40) in the canyon, and a succession of large fossil canyons, with a fossil axial incision (Fig. 10-B). Seawards, in the middle canyon, the same sequences are shown on profile 6024 (Fig. 10-C).

In summary we observe that:

(i) axial incisions show different patterns (from meandering to slightly sinuous) and appear well developed on the present floor of Cap Creus, Lacaze-Duthiers, Bourcart-2, Hérault-2 and Hérault-3 canyons. It is smoothed on the present floor of Pruvot and Bourcart-1 canyons and it is absent in Hérault-1, Hérault-4, and Sete canyons (infilled canyons) (Fig. 2),

(ii) erosional structures related to fossil axial incisions are seen in multichannel seismic profiles and correlate to the major discontinuities observed on the outer shelf,

(iii) the multi-channel seismic data in the interfluve (Fig. 9) illustrate the evolution of major discontinuities that show the progradation of the sediments in a zone not affected by the presence of canyons,

(iiii) the seismic data crossing the canyon show the infill of the upper canyon head (Fig. 8A) and the progressive widening and deepening of the canyon downslope (Figs. 8B and 10). 


\section{Discussion}

The submarine canyons in the Gulf of Lion have a complex history with phases of deposition and of erosion. Two main erosive features, of very different dimensions, can be observed: (i) the axial incision and (ii) the canyon's major valley.

The axial incision is defined as the downcutting of the canyon floor during rejuvenation. The most probable mechanism for its formation is the erosion by turbidity currents. They can be generated by: (a) direct connection with turbulent fluvial flow (hyperpycnal turbidity current) or (b) the down slope evolution of mass wasting processes, affecting sediment previously deposited at the shelf edge and/or slope (dilute turbidity currents).

The first hypothesis (river connection) is favoured by the fact that axial incisions start around $110 \mathrm{~m}$ water depth, which roughly corresponds to the sea level position during LGM in the Gulf of Lion (Lambeck and Bard, 2000). The meandering shape of the axial incision within the Bourcart canyon suggests the existence of maintained flows. Considering the initiation of axial incisions (Fig. 5-A) and their length (more than $50 \mathrm{~km}$ ), it is not possible that they result from slope failure. Maar (1999) has shown that the conversion of failuregenerated land-slides to dilute turbidity currents is an inefficient process for erosion (in Parsons et al., 2001). Only hyperpycnal plumes generated by flooding rivers (Mulder \& Syvitski, 1995) have the sufficient duration and magnitude for generating such axial incisions. All the canyon heads where axial incisions are observed correspond to the seaward 
termination of streams whose retreat path during the post LGM sea-level rise is marked by both erosion and sediment accumulation across the shelf (Berné et al., 2002).

This interpretation is supported by the fact that, during glacial periods, an important continental run off (due to presence of glaciers in the Alps and Pyrenees) increased the direct delivery of sediments to the canyon heads.

The period of activity of the axial incision can be accurately estimated in the Bourcart canyon where it erodes a distinct notch which can be traced all around the continental shelf in the Gulf of Lion (Berné et al., 1998b). This notch represents the seaward termination of shoreface sands deposited during the forced regression induced by sea-level fall prior to the LGM (Rabineau et al., 1998 ; Berné et al., 2002; Rabineau et al., this issue). This means that the axial incision was still active during the LGM, when the forced regressive shoreface sands were deposited. Only a thin veneer $(<1 \mathrm{~m})$ of post-glacial deposits, representing the transgressive and highstand condensed deposits, covers the lowstand deposits on the outer shelf(Got, 1973; Berné 1998a).

However slope instabilities are also observed on the flanks of the canyons, and bring some sediment transported through the axial incision. In the Lacaze-Duthiers canyon (Berné \& Loubrieu, 1999), and the branches 2 and 3 of the Hérault canyon, the axial incision is in continuity with canyon head where slump scars suggest a retrogressive mechanism (Fig. 6A).

In summary, we interpret the axial incision observed at the present sea floor as the erosive path related to the passage of hyperpycnal turbidity currents, generated up-slope by 
river connection during LGM. This erosion trigger mass wasting that affects the canyon's major valley (flanks and head), as modeling by Pratson and Coakley (1996) suggested.

\section{Formation of the canyon's major valley}

The canyons' major valleys in the Gulf of Lion, with subregular flanks of more than 700 $\mathrm{m}$ height, can not be the result of a single erosive episode (as already discussed by Shepard (1936)). Their flanks are five time greater than the height of the active feeder channels of the largest deep sea fans in the world that are, for instance, $195 \mathrm{~m}, 200 \mathrm{~m}, 100$ and $50 \mathrm{~m}$, for the Indus, the Amazon, the Rhone and the Mississippi channels, respectively (Clark \& Pickering 1996).

We showed that the axial incision induces instabilities on canyons flanks through erosion. Fig. 11 shows the interpretation of structures observed in Fig. 8-B. In the vicinity of the axial incision we observe perturbed, stretched and eroded sediments related to the axial incision activity. This perturbation triggers major slumps as observed on the western flank

(Fig. 11). Those slumps have eroded a large amount of sediments that have been subsequently transported downslope via the axial incision.

We propose a scenario for the evolution of the upper Bourcart canyon (Fig. 12) based on seismic data from Fig. 8. This evolution is explained through time between D60 and D70LGM discontinuity.

i) The start point (Fig. 12-A-1) is a fossil incised stage, related to low sea level (D-60) during the glacial maximum of isotopic stage 6. 
ii) During the next step, the canyon head is partially filled with sediments from the river plumes and benthic boundary layers (Fig. 12-A-2). In this stage sediment fill and the canyon are stable, as we can see in the conformable reflectors from the infilled Hérault branch (Fig. 4-B) and in the sediments olders than -and not affected by- the axial incision (Fig. 8).

iii) In the $3^{\text {rd }}$ step, the lowering of sea level brings the shoreline near the canyon head, and an early river connection is established. The sediment input increases and turbidity currents start to erode the floor of the canyon (Fig. 12-A-3).

iiii) During the last stage of lowering of sea level and LGM, sedimentation rate increase around canyons heads because of sea-level fall that shortens the distance between rivers and the shelf edge. When the shoreline is close to the canyon head, hyperpycnal turbidity currents erode the floor of the canyon generating the axial incision (Fig. 12-A-4). During this stage the undercutting of the floor by axial incision triggers slides and creates small failures and sliding surfaces in the sedimentary filling; those destabilizations induce in turn instabilities and retrogressive slumps along the main flanks of the canyons (Fig. 11). The re-mobilized sediments are drained by the turbidity currents downslope.

If no stream connects to the canyon head during the minimum stage of sea level, no axial incision occurs and sediment fill remains stable (Fig. 12-A2).

Using the interpretation of multichannel seismic data (Fig. 10-C) we are able to reconstruct the canyon evolution through time, from 400000 years to present (Fig. 13). We show that the gradual widening and deepening of the middle canyon (cycle after cycle, during each glacial maximum) is related to the activity of axial incision. 
Together with the widening and deepening of the canyon's major valley (as a consequence of the recurrent axial incision activity during each glacial maximum) (Fig. 8-A and Fig. 13) the upper-most canyon head (Fig. 8-B) is infilled as a consequence of the overall progradation of the margin. 


\section{Conclusion}

This work demonstrates the presence of an axial incision in most submarine canyons in the western part of the Gulf of Lion. The height of these axial incisions ranges from 40 to 150 m. They create a small axial erosive path within the erosive canyon's major valley, bounded by flanks of more than 700 meters in height.

-The axial incision, observed at the present sea floor, is an erosive minor feature observed in most canyons and interpreted as the imprint of hyperpycnal turbidity currents that eroded the floor of canyons and drained sediments downslope during connection to active rivers during the Last Glacial Maximum.

-The minor erosion related to the axial incision, however, has a key influence on canyon evolution as it triggers mass wasting of different sizes that affect the canyon's major valley (head and flanks) (Fig. 11).

-Axial incisions and associated discontinuities are correlated to major erosional surfaces related to 100000 years glacioeustatic -interglacial/glacial- cycle (Rabineau, 2001 and this issue). Therefore axial incision show recurrent activity corresponding to 100000 years glacial cycles for the last 400000 years.

-The canyon's major valley can not be the result of a single erosive episode. The widening, deepening of the canyon's major valley is the consequence of the recurrent erosive activity of the axial incision during each glacial maximum (Fig.13). 
The scenario proposed in this paper should not be applied directly to all types of margins. The study area shows a combination of local conditions: a prograding margin with high sediment load, shelf of $50 \mathrm{~km}$ (average slope $\left.<0.57^{\circ}\right)$, a low continental slope $\left(1.5^{\circ}\right)$ and highstand deposits trapped in the inner shelf, so that river connection and major canyon activity only occur around glacial maxima. 


\section{Acknowledgements}

This research is supported by the European Community through the Eurostrataform project (contract EVK3-2001-00200) and the French program "GRD-Marges". Herve Nouze and Benoit Loubrieu are thanked for seismic and bathymetric data processing, respectively.

The authors are grateful to Lincoln Pratson and Thierry Mulder whose reviews improved the manuscript. 


\section{Figure Captions}

Figure 1: General bathymetric map of the western Gulf of Lion showing the three main physiographic areas: the continental shelf $\left(0.1^{\circ}\right)$ the continental slope $\left(1.5^{\circ}\right)$ and the rise $\left(0.9^{\circ}\right)$. The plain bold line is the shelf break. The dashed line is the slope break. The doted line is the Last Glacial Maximum shoreface. CCC: Cap Creus Canyon; LDC: Lacaze-Duthiers Canyon; PVC: Pruvot Canyon; BCC: Bourcart Canyon; HRC: Hérault Canyon; STC: Sète Canyon; MAC: Marty Canyon.

Figure 2: Simplified and shaded bathymetric map of the western Gulf of Lion showing the different types of canyon. Dots represent an incision that has been smoothered. The different branches of canyons are numbered in a clockwise direction. Boxes show the position of figures presented in this paper.

Figure 3: Sketch of a canyon showing the difference between the canyon's major valley and the axial incision. In frame B we can see some of the measured parameters: WFH; canyon's major valley west flank height, EFH; canyon's major valley east flank height, MVW; canyon's major valley width, and the axial incision height and width. The axial incision potential infill quantifies the minimum amount of material eroded from the canyon floor and transported downslope through the axial incision.

Figure 4: Hérault Canyon head. A) detailed bathymetric map of Branches H1, H2 and H3 (see Fig. 2 for location) with the position of Sparker seismic lines. B) Seismic line across 
branch H1 showing an infilled canyon. C) Seismic line across H2 and H3 showing infilled/incised branches with axial incisions.

Figure 5: Incised head of Bourcart Canyon (BCC2). A) detailed bathymetric map (see Fig. 2 for location) with the position of sparker seismic lines showed in Fig. 8. B) Longitudinal profile along BCC2 canyon, showing the evolution of the depth of the thalweg with the distance from the head, the height of the canyon's major valley flanks and the height of the axial incision flanks.

Figure 6: Lacaze-Duthiers Canyon. A) detailed bathymetric map (see Fig. 2 for location) with the position of the seismic line showed in B. B) GI-Gun seismic profile (with a resolution of about $20 \mathrm{~m}$ ) across the canyon showing an infilled/incised canyon. C) Longitudinal profile along canyon, showing the evolution of the depth of the thalweg with respect to the distance from the head, the height of the canyon's major valley flanks and the height of the axial incision flanks.

Figure-7: Cap Creus Canyon. A) detailed bathymetric map (see Fig. 2 for location) with the position of the seismic line showed in B. B) GI-Gun seismic profile (with a resolution of about $20 \mathrm{~m}$ ) across the canyon showing an incision. C) Longitudinal profile along the canyon, showing the evolution of the depth of the thalweg with respect to the distance from the head, the height of the canyon's major valley flanks and the height of the axial incision flanks.

Figure-8: Interpretation of Sparker seismic lines from CALMAR-99 cruise (see location in Fig. 5) A) 5083 line in the uppermost canyon head where the progradation of the margin is 
expressed in the progressive filling of the canyon's major valley, B) 5089 line located $3 \mathrm{~km}$ downslope of frame A, showing the consequences of the axial incision activity on its flanks and on the main canyon flanks.

Figure 9: A and C) Multichannel seismic line 6012 from MARION cruise showing the evolution of main discontinuities (D-70, D-60, D-50 and D-40) in the BCC-HRC interfluve, where the sedimentation is not perturbed by the existence of the canyons (see Fig. 2 for location). B) Simplified sea level curve (Waelbroeck et al., 2002) showing the successive lowstands related with incised stages ( D-40, D-50, D-60 and LGM).

Figure 10: Depth migrated seismic lines 6020 and 6024 A) line 6020 (same location as sparker line 5086 from Fig. 8-B), B) Zoom from line 6020 showing fossil axial incisions associated with main discontinuities and C) line 6024, seaward in the middle canyon (see Fig. 2 for location), showing the deepest and widest canyon seismic expression.

Figure-11: Detail of line 5089 (see location in Fig. 8-B) showing the role of the axial incision. We show that the axial incision induces instabilities in canyons through erosion. In the vicinity of the axial incision we observe perturbed stretched and eroded sediments related to the axial incision activity. This perturbation triggers major slumps as observed on the western flank. Those slumps have eroded a large amount of sediments that have been subsequently transported downslope via the axial incision. We show that the axial incision is the mechanism that controls the deepening and widening of canyons' major valleys. 
Figure-12: A) Simplified scenario for the evolution of the Bourcart canyon through time with phases of deposition and erosion, line 5083 is located in the uppermost canyon head and line 5089 is located $3 \mathrm{~km}$ downslope (see location in Fig. 5). A-1) Inherited stage from previous lower sea level; A-2) early filling of the canyon from head to slope during phases of lowering of sea-level; A-3) early incised stage related with lowstand and A-4) axial incision at lowstand with a river connection and turbidity currents, the incision erodes previously deposited triggering slides in flanks and head, the re-mobilized sediments are drained downslope during connection stage; A-1) and so forth... B) Sea level curve (Waelbroeck et al., 2002) showing the relation between sea level and sedimentation/erosion periods for the last cycle (from D-60 to LGM)

Figure 13: A) Sea level curve (Waelbroeck et al., 2002) showing the successive lowstand related with incised stages ( D-40, D-50, D-60 and LGM). B) Simplified scenario for the evolution of the middle canyon through successive lower sea levels. Step by step we show the progressive widening and deepening of the canyon (in its middle course). Each step is related to incised stages from lowstands.

Figure 14: Sea level curve (Waelbroeck et al., 2002) showing the successive lowstands related with incision stages ( D-40, D-50, D-60 and LGM) and the simplified scenario for canyon evolution related with Quaternary glacial/interglacial 100,000yrs cycles for the last 400000 yrs. 


\section{Table}

Table 1: Morphometric data for the submarine canyons of the Western Gulf of Lion. Values obtained from the analysis of cross sections perpendiculars to the thalweg. Ranges are defined in a seaward direction. The parameters are: Az; azimuth; WFH; west flank height, EFH; east flank height, FsAH; flanks average height, AW; canyon's major valley average width, W/H; canyon's major valley width/height ratio. Axial incisions volumes are also summarized. The estimated volume quantifies the minimum material eroded from the canyon floor and transported downslope through the axial incision (the total sediment volume removed is 11.4

$\mathrm{km}^{3}$ ). Value obtained for the Lacaze-Duthiers canyon suggests that this canyon had a particularly important activity. 


\section{References}

Aloïsi, J.-C., Cambon, J.-P.and Carbonne, J.(1982). Origine et rôle du néphéloïde profond dans le transfert des particules au milieu marin. Application au Golfe du Lion, Oceanologica Acta, 481-491.

Aloïsi, J.C., Millot, C., Monaco, A. and Pauc, H. (1979). Dynamique des suspensions et mécanismes sédimentologiques sur le plateau continental du Golfe du Lion. CRAS, 289, 879882.

Aloïsi, J.C., Barusseau, J.-P. and Monaco, A. (1975). Rôle des facteurs hydrodynamiques dans la sédimentation des plateaux continentaux. CRAS, 280, 579-582.

Alonso, B., Canals, M., Got, H. and Maldonado, A. (1991). Sea valleys and related depositional systems in the Gulf of Lion and Ebro continental margin. AAPG Bulletin, 75(7), $1195-1214$.

Bellaiche, G., Aloïsi, J.C. and Berthon, J.L. (1983). Morphologie au Sea-Beam de l'éventail sous-marin profond du Rhône (Rhône deep-sea fan), Commiss. Internationale Explor. Sci. Mer Mediterranée Rapp. P.V. réunions Monaco, pp. 61-62.

Berné, S., Aloïsi, J. C., Baztan, J., Dennielou, B., Droz, L., Dos Reis, T., Lofi, J., Méar, Y., Rabineau, M., Satra, C. (2002). Notice de la carte morpho-bathymétrique du Golfe du Lion, IFREMER et Région Languedoc Roussillon, Brest 
Berné, S., Loubrieu, B. and the "Calmar 97" Shipboard Party (1999). Canyons and recent sedimentary processes on the western Gulf of Lions margin. First results of the Calmar cruise. CRAS, 328, 471-477.

Berné, S., Canals, M., Alonso, B., Loubrieu, B. and Cochonat, P., and the "Big 95" and "Calmar 97" Shipboard Parties. (1998a). Recent slope failures and mass-movements in the NW Mediterranean Sea. In: European Commission, M.P., Dg Xii/D-3 (Editor), Proceedings of the seafloor characterisation/mapping session, Mast days, Lisbon.

Berné, S., Lericolais, G., Marsset, T., Bourillet, J.F. and De Batist, M. (1998b). Erosional offshore sand ridges and lowstand shorefaces: examples from tide and wave dominated environments of France. Journal of Sedimentary Research, 68(4), 540-555.

Bourcart, J. (1960). Carte topographique du fond de la Méditerranée occidentale. Bull. Inst. Océanogr., 1163, 1-20.

Bourcart, J., De La Bernardie, A. and Lalou, C. (1948). Le rech Lacaze-Duthiers, canon sousmarin du plateau continental du Roussillon. CRAS, 226(20), 1632-1633.

Canals, M., Casamor, J.L., Urgelés, R., Lastras, G., Calafat, A.M., De Batist, M., Masson, D.G., Berné, S. and Alonso, B. (2000). The Ebro Continental margin, Western Mediterranean Sea: Interplay between canyon-channel systems and mast wasting processes: GCSSEPM Foundation, $20^{\text {th }}$ Annual Research Conference, Houston, Texas 
Canals, M. (1985). Estructura sedimentaria y evolucion morfologica del talud y el glacis continentales del Golfo de Leon: fenomenos de destabilizacion de la coberta sedimentaria plio-cuaternaria. Ph. D. Thesis, University of Barcelona, Barcelona, 618 pp.

Clark, J.D. and Pickering, K.T. (1996). Submarine channels. Processes and architecture: Vallis Press, London (UK), p. 231

Daly, R. A. (1936). Origin of the submarine canyons: A. Jour. Sci., $5^{\text {th }}$ ser., v. 31 p. 401-420

Dana, J. D., 1863. A manual of geology. Philadelphia, 798 pp.

Dos Reis, T., Gorini, C., Mauffret, A. (this issue) Implications of salt-sediment interactions for the architecture of the Gulf of Lions deep water sedimentary systems (Western Mediterranean Sea)

Dos Reis, T. (2001). La Tectonique Salifère et son influence sur l'Architecture Sédimentaire Quaternaire de la Marge du Golfe du Lion-Méditerranée Occidentale. Ph. D. Thesis, Université de Paris 6, 216 p. +157 pp.

Droz, L. Kergoat, R., Cochonat, P. and Berné, S. (2001). Recent sedimentary events in the western Gulf of Lion (Western Mediterranean). Marine Geology, 176 (1-4) 23-37

Droz, L. (1991). Morphologie, structure et comparaison des deep sea fans du Rhône, de l'Indus et du Var. Mémoire d'habilitation. Université Paris 6, Paris, 254 pp. 
Droz, L. and Bellaiche, G. (1985). Rhône deep-sea fan: morphostructure and growth pattern. American Association of Petroleum Geologists Bulletin, 69, 460-479.

Duplaix, S. and Olivet, J.L. (1971). Etude sédimentologique et morphologique de la tête du rech Bourcart (Golfe du Lion). CRAS.

Farre, J.A., Mcgregor, B.A., Ryan, W.B.F., Robb, J.M., Stanley, D.J. and Moore, G.T. (1983). Breaching the shelfbreak; passage from youthful to mature phase in submarine canyon evolution In: The shelfbreak; critical interface on continental margins. Special Publication Society of Economic Paleontologists and Mineralogists, 33, 25-39.

Glangeaud, L., Bellaiche, G., Gennesseaux, M. and Pautot, G. (1968). Phenomenes pelliculaires et epidermiques du rech Bourcart (golfe du Lion) et de la mer hesperienne. CRAS, 267(13), 1079-1083.

Got, H. and Stanley, D.J. (1974). Sedimentation in two Catalonian canyons, northwestern Mediterranean. Marine Geology, 16, 91-100.

Got, H. (1973). Etude des corrélations tectonique-sédimentation au cours de l'histoire quaternaire du précontinent pyrénéo-catalan. Thèse de Docorat d'Etat, Université de Perpignan, Université de Perpignan, 294 pp.

Kenyon, N.H., Millington, J., Droz, L. and Ivanov, M.K. (1995). Scour holes in a channellobe transition zone on the Rhone cone. In: Pickering, K.T., Hiscott, R.N., Kenyon, N.H., 
Ricci Lucchi, F. and Smith, R.D.A. (Editors), Architectural styles in turbidites systems. Chapman \& Hall, London, pp. 212-215.

Kuenen, Ph.H. (1938). Density currents in connection with the problem of submarine canyons. Geological Magazine, 888(75), 241-249.

Lambeck, K. and Bard, E. (2000). Sea-level change along the French Mediterranean coast for the past 30000 years. Earth and Planetary Science Letters, 175, 203-222.

Maar, J.D.G. (1999). Experiments on subaqueous sandy gravity flows: flow dynamics and deposits structures. MsC Thesis, University of Minnesota.

Millot, C. (1990). The Gulf of Lions' hydrodynamics. Continental Shelf Research, 10(9-11), 885-894.

Monaco, A., Heussner, S., Courp, T., Buscail, R., Fowler, S.W., Millot, C. and Nyffeler, F. (1987). Particle supply by nepheloid layers on the Northwestern Mediterranean Margin In: Particle flux in the ocean; Proceedings of a workshop sponsored by the Deutsche Forschungsgemeinschaft (DFG) and the Turkish Research Council (Tubitak), at the Dokuz Eylul University, Izmir, Turkey, June 23-28, 1986; SCOPE/ UNEP Sonderband. Mitteilungen aus dem Geologisch-Palaeontologischen Institut der Universitaet Hamburg, 62, 109-125. 
Monaco, A. (1971). Contribution à l'étude géologique et sédimentologique du plateau continental du Roussillon. Thèse de Doctorat d'Etat Thesis, Université de Perpignan, Perpignan, $295 \mathrm{pp}$.

Mountain, G.S., Damuth, J.E., Mchugh, C.M.G., Lorenzo, J.M. and Fulthorpe, C.S. (1996). Origin, reburial, and significance of a Middle Miocene canyon, New Jersey continental slope. In: Mountain, G.S., Miller, K.G., Blum, P., Poag, C.W. and Twichell, D.C. (Editors), Proceedings of the Ocean Drilling Program, Scientific Results. Ocean Driling Program, College Station, Texas, pp. 283-292.

Mulder, T. and Syvitski, J.P.M. (1995). Turbidity currents generated at river mouths during exceptional discharges to the world oceans. Journal of Geology, 103, 285-299.

O'connell, S., Ryan, W.B.F. and Normark, W.R. (1987). Modes of development of slope canyons and their relation to channel and levee features on the Ebro sediment apron, off-shore northeastern Spain. Marine and Petroleum Geology, 4, 308-319.

Parsons, J.D., Bush, J.W.M. and Syvitski, J.P.M. (2001). Hyperpycnal plume formation from riverine outflows with small sediment concentrations. Sedimentology, 48(2), 465-478.

Pratson, L.F. and Coakley, B.J. (1996). A model for the headward erosion of submarine canyons induced by downslope-eroding sediment flows.. Geological Society of America Bulletin, 108(2), 225-234. 
Pratson, L.F., Ryan, W.B.F., Mountain, G.S. and Twichell, D.C. (1994). Submarine canyon initiation by downslope-eroding sediment flows; evidence in late Cenozoic strata on the New Jersey continental slope. Geological Society of America Bulletin, 106(3), 395-412.

Rabineau, M., Berné, S., Aslanian, D., Olivet, J. L., Joseph, P., Guillocheau, F. (this issue) Sedimentary sequences in the Gulf of Lions: a record of 100,000 years climatic cycles.

Rabineau, M. (2001). Un modèle géométrique et stratigraphique des séquences de dépôts quaternaires de la plate-forme du Golfe du Lion : enregistrement des cycles glacioeustatiques de 100000 ans. Ph. D. Thesis, Université de Rennes 1, 445 pp.

Rabineau, M., Berné, S., Le Drezen, E., Lericolais, G. and Rotunno, M. (1998). 3D architecture of lowstand and transgressive Quaternary sand bodies on the outer shelf of the Gulf of Lions, France. Marine and Petroleum Geology, 15(5), 439-452.

Shepard. F.P. (1936). The underlying causes of submarine canyons: Natl. Acad. Sci. Natl. Research Council Pub., V. 22, p. 496-502

Slater, R. A. (1981). Submarine observations of the sea floor near the proposed George Bank lease sites along the North Atlantic outer continental shelf and upper slope: U.S. Geol. Survey Open File Rept., pp. 81-742

Stanley, D.J., and Silverberg, N. (1969). Recent Slumping on the continental slope off Sable Island Bank, Southeast Canada. Earth and Planetary Science Letters, 6: 123-133 
Torres, J., Droz, M., Savoye, B., Terentieva, E., Cochonat, P., Kenyon, N.H. and Canals, M. (1997). Deep-sea avulsion and morphosedimentary evolution of the Rhône Fan Valley and Neofan during the Late Quaternary (northwestern Mediterranean Sea). Sedimentology, 44, 457-477.

Torres, J. (1995). Analyse détaillée du transfert de sédiment du continent vers le bassin : Le quaternaire terminal au large du Delta du Rhône (Méditerranée nord-occidentale). Phd Thesis, Université de Bretagne Occidentale, 353 pp.

Twichell, D.C. and Roberts, D.G. (1982). Morphology, distribution, and development of submarine canyons on the United States Atlantic continental slope between Hudson and Baltimore canyons. Geology, 10, 408-412.

Veatch, A. C., and Smith, P. A. (1939). Atlantic submarine valleys of the United States and Congo Submarine Valley: Geol. Soc. America Spec. Paper n. 7, 101 pp.

Waelbroeck, C., Labeyrie, L. D., Michel, E., Duplessy, J-C., J. McManus, K. Lambeck, E. Balbon and Labracherie, M. (2002). Sea level and deep water changes derived from benthic Foraminifera isotopic record, Quaternary Science Review 21(1-3), 295-305. 


\begin{tabular}{|c|c|c|c|c|c|c|c|c|c|c|c|}
\hline & $\begin{array}{l}\text { Az } \\
\left({ }^{\circ}\right)\end{array}$ & $\begin{array}{l}\text { Depth range } \\
\text { (m) }\end{array}$ & $\begin{array}{l}\text { Thalweg } \\
\text { length } \\
\text { (m) }\end{array}$ & $\begin{array}{l}\text { Canyon } \\
\text { length } \\
(\mathbf{k m})\end{array}$ & Sinuosity & $\begin{array}{c}\text { WFH(max) } \\
\text { (m) }\end{array}$ & $\begin{array}{c}\text { EFH(max) } \\
\text { (m) }\end{array}$ & $\begin{array}{c}\text { FsAH } \\
\text { (m) }\end{array}$ & $\begin{array}{c}\mathbf{A W}(\max ) \\
(\mathrm{m})\end{array}$ & $\mathbf{W} / \mathbf{H}$ & $\begin{array}{l}\text { Vol. } \\
\left(\mathrm{km}^{3}\right)\end{array}$ \\
\hline CC-CANYON & 120 & $120-1850$ & 106 & 91 & 1.16 & $339(830)$ & $279(513)$ & 309 & $6405(13856)$ & 30 & - \\
\hline CC-INCISION & & $640-1650$ & - & - & - & - & - & $\begin{array}{c}100 \\
\text { (range } 150-35 \text { ) }\end{array}$ & $\begin{array}{c}1400 \\
\text { (range 1800-950) }\end{array}$ & - & 2.28 \\
\hline LD-CANYON & 124 & $110-1850$ & 105 & 89 & 1.18 & $407(788)$ & $435(768)$ & 416 & $8134(13278)$ & 27 & - \\
\hline LD-INCISION & & $500-1700$ & - & - & - & - & - & $\begin{array}{c}150 \\
\text { (range 240-60) }\end{array}$ & $\begin{array}{c}1800 \\
\text { (range 2400-1100) }\end{array}$ & - & 6.20 \\
\hline PR-CANYON & 136 & $124-1340$ & 42 & 36 & 1.16 & $235(393)$ & $181(345)$ & 208 & $3369(5609)$ & 22 & - \\
\hline BC2-CANYON & 150 & $110-1690$ & 68 & 62 & 1.09 & $361(895 ?)$ & $269(828)$ & 315 & $4685(7300)$ & 22 & - \\
\hline BC2-INCISION & & $110-1700$ & - & - & - & - & - & $\begin{array}{c}50 \\
\text { (range 80-10) }\end{array}$ & $\begin{array}{c}900 \\
\text { (range } 1400-500 \text { ) }\end{array}$ & - & - \\
\hline HR2-CANYON & 159 & $110-470$ & 7,2 & 7 & 1.3 & $132(231)$ & $154(420)$ & 143 & $2435(3035)$ & 21 & - \\
\hline HR3-CANYON & 158 & $110-767$ & 23 & 20 & 1.1 & $285(770)$ & $308(770)$ & 297 & $4545(6652)$ & 22 & - \\
\hline HR2and3-INCISION & & $110-1800$ & - & - & - & - & - & $\begin{array}{c}40 \\
\text { (range 20-100) } \\
\end{array}$ & $\begin{array}{c}700 \\
\text { (range } 1200-450 \text { ) } \\
\end{array}$ & & 2.02 \\
\hline HR4-CANYON & 148 & $130-1913$ & 64 & 53 & 1.20 & $265(425)$ & $345(670)$ & 298 & $10829(6200)$ & 23 & - \\
\hline ST1-CANYON & - & 154-1057 & 15 & 12 & 1.22 & $338(720)$ & $224(457)$ & 323 & 5554 (7184) & 24 & - \\
\hline ST2-CANYON & 150 & $158-2116$ & 88 & 74 & 1.18 & $626(1065)$ & $299(620)$ & 470 & $6423(9442)$ & 18 & - \\
\hline
\end{tabular}

Table 1, Baztan et al. 


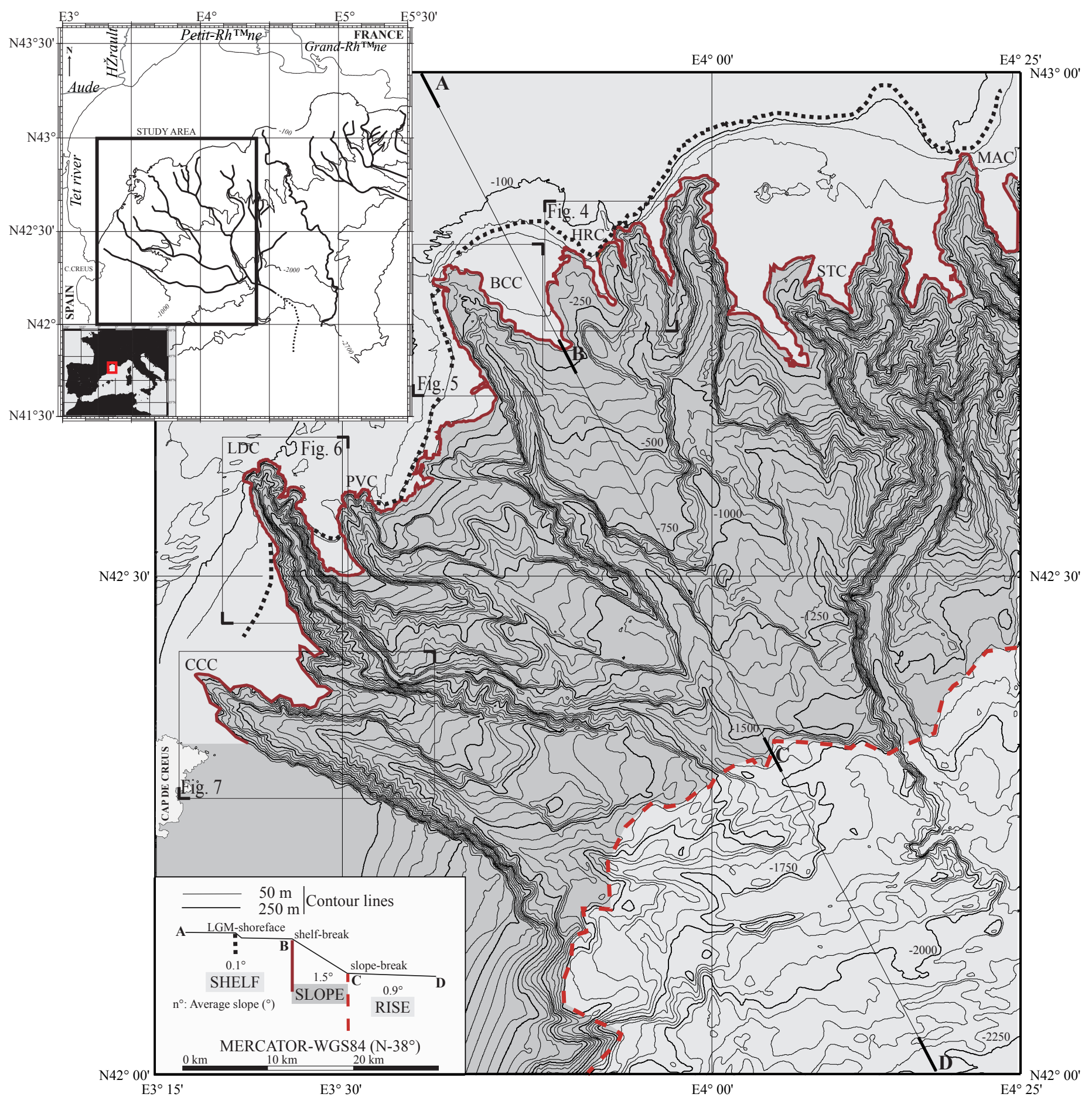

Figure 1, Baztan et al. 


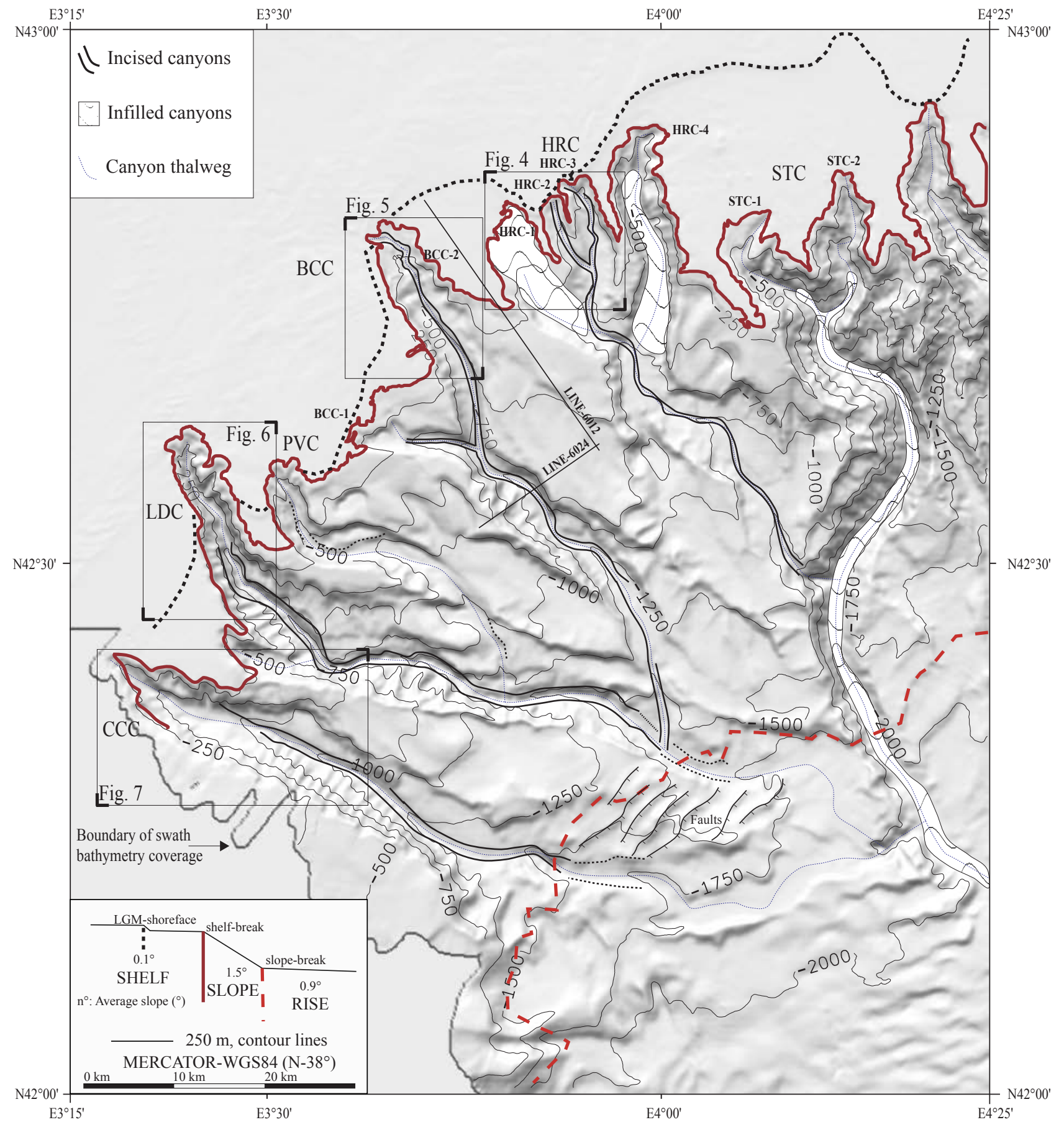

Figure 2, Baztan et al. 

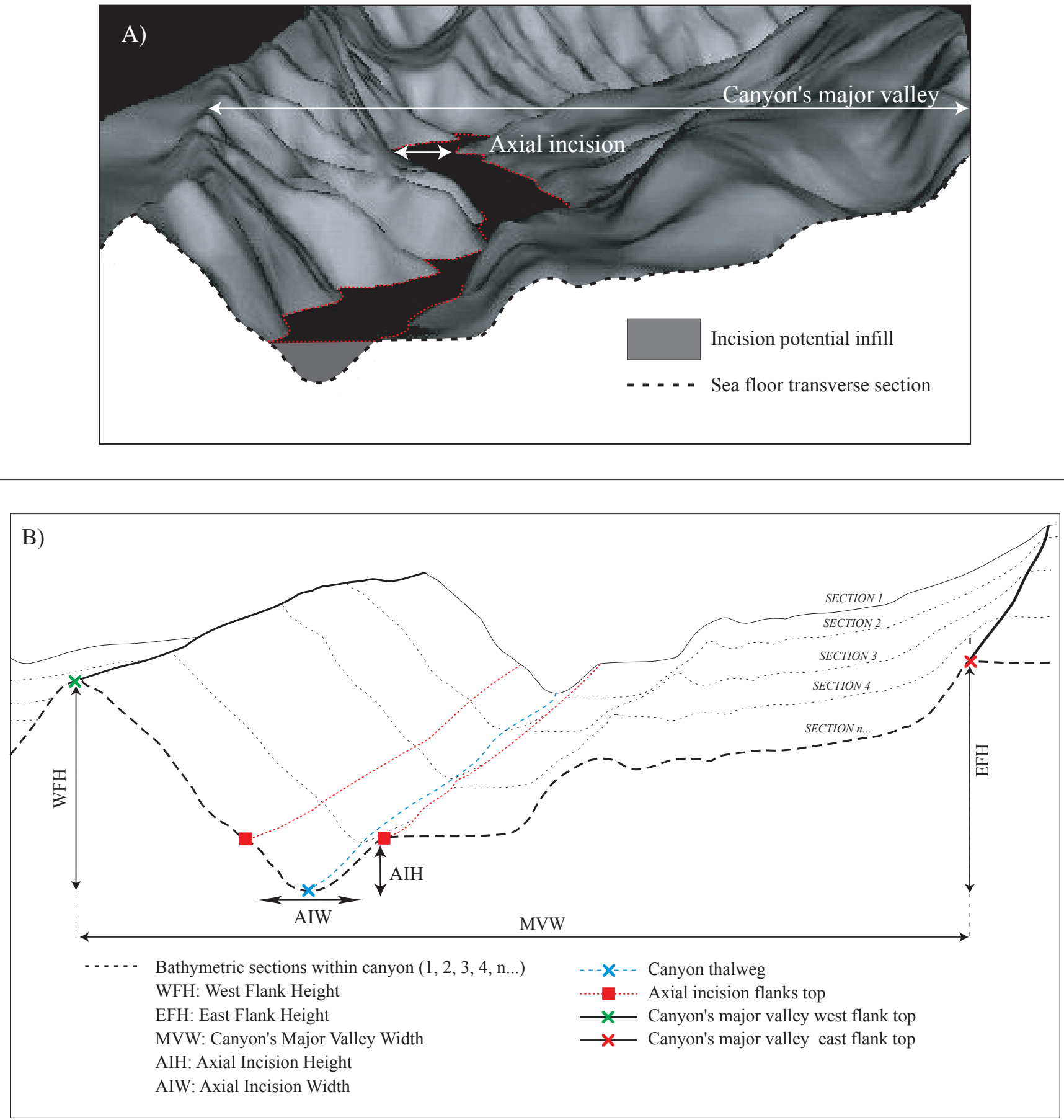

Figure 3, Baztan et al. 

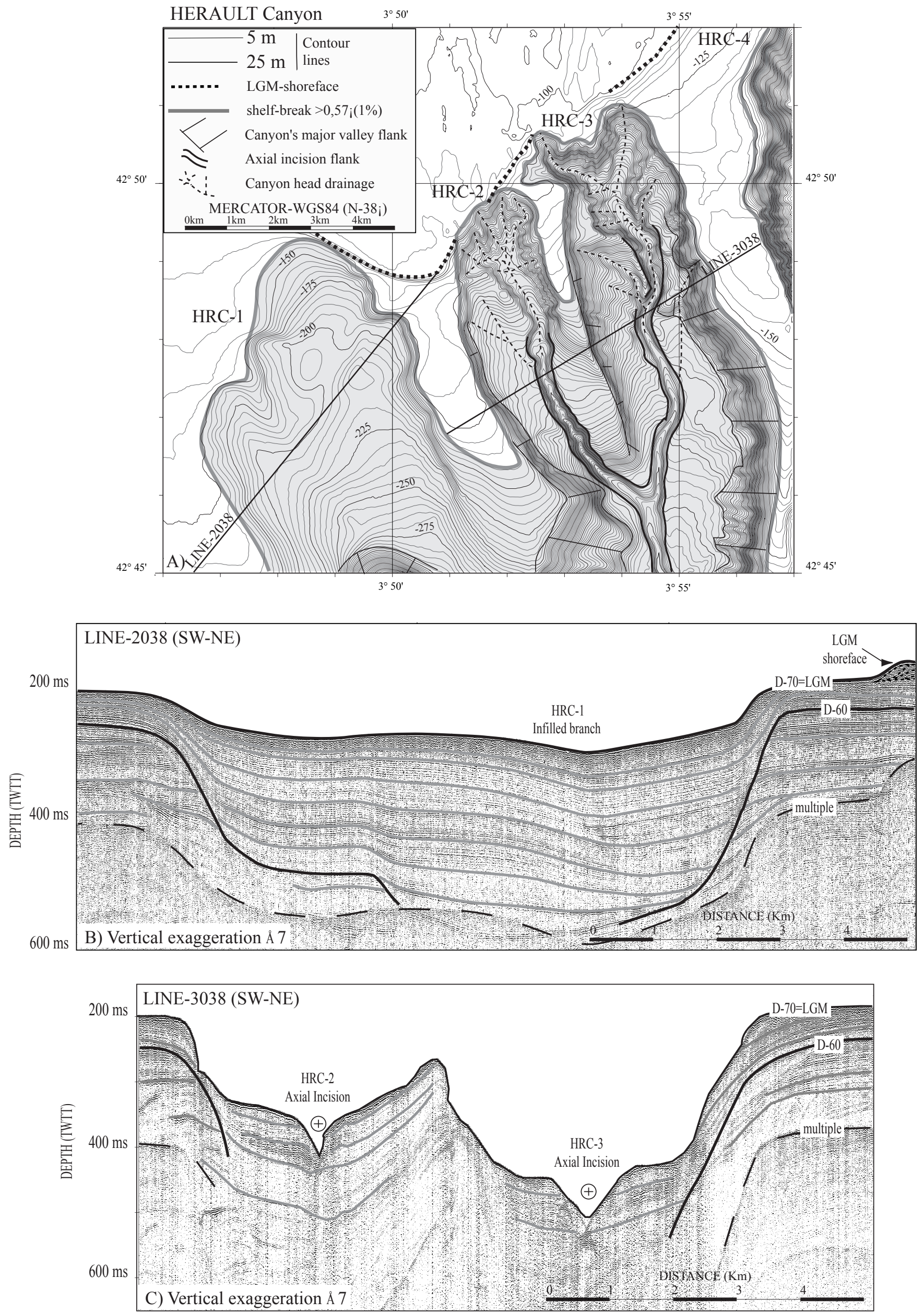

Figure 4, Baztan et al. 

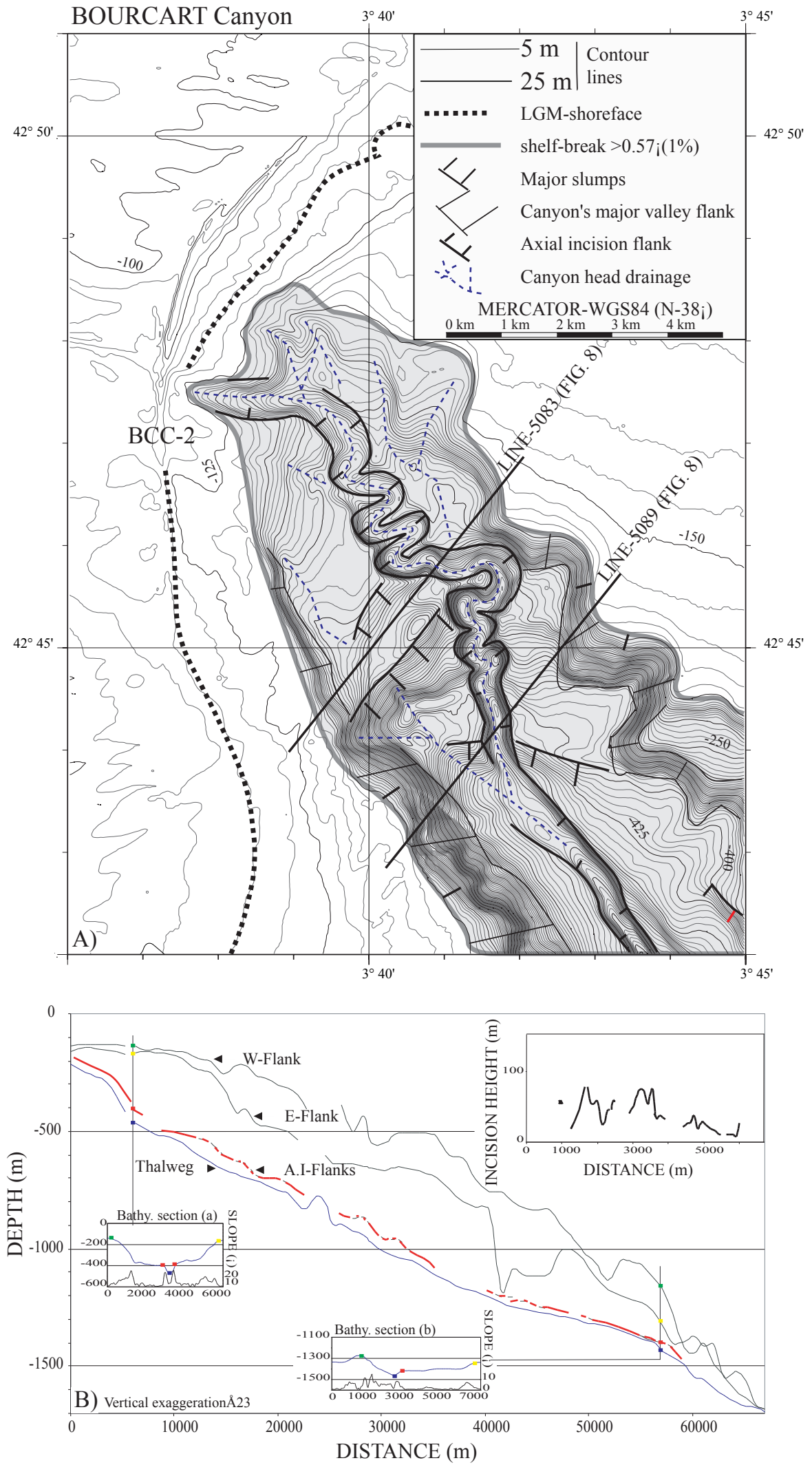

Figure 5, Baztan et al. 


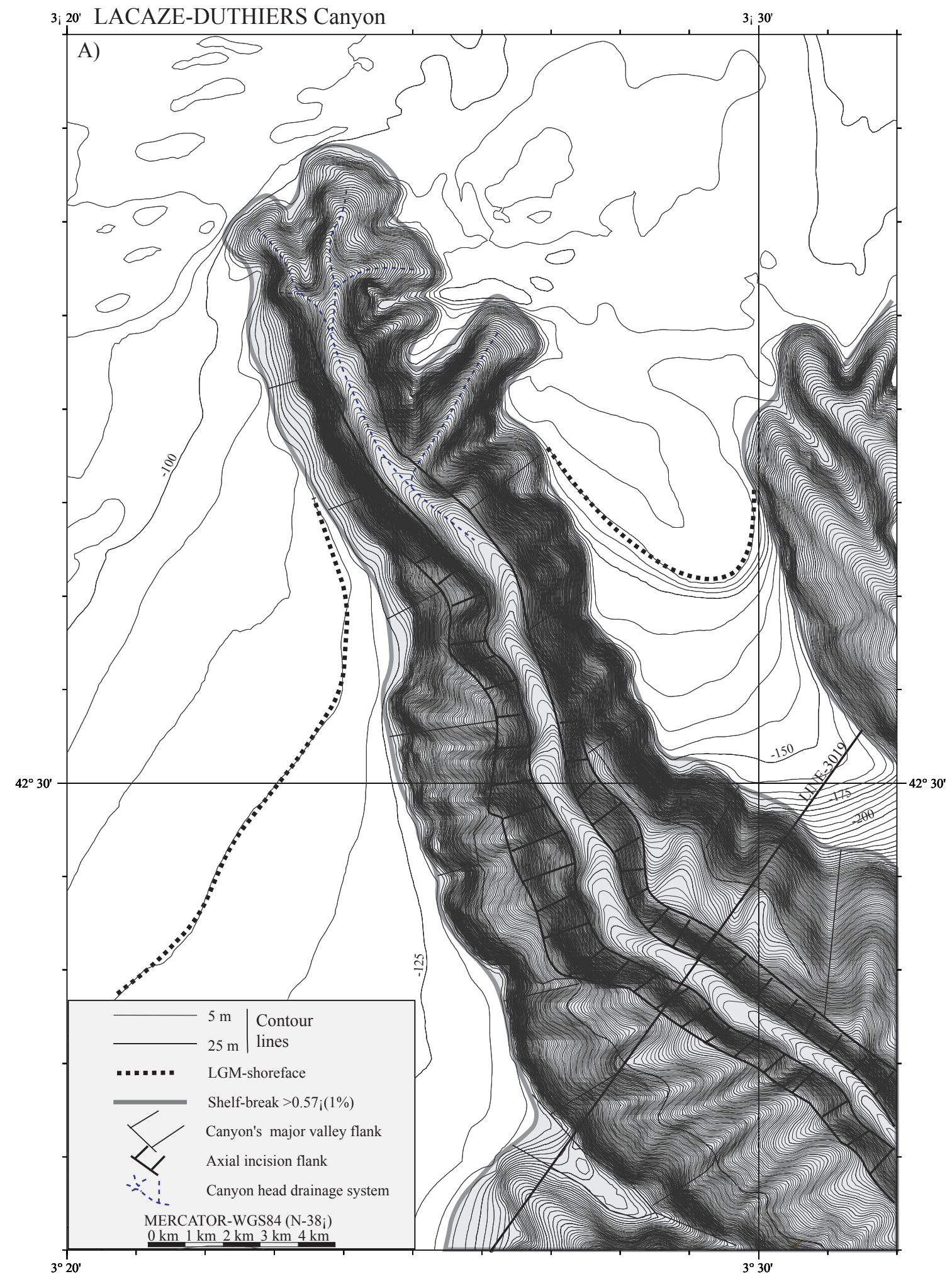

Figure 6-A, Baztan et al. 

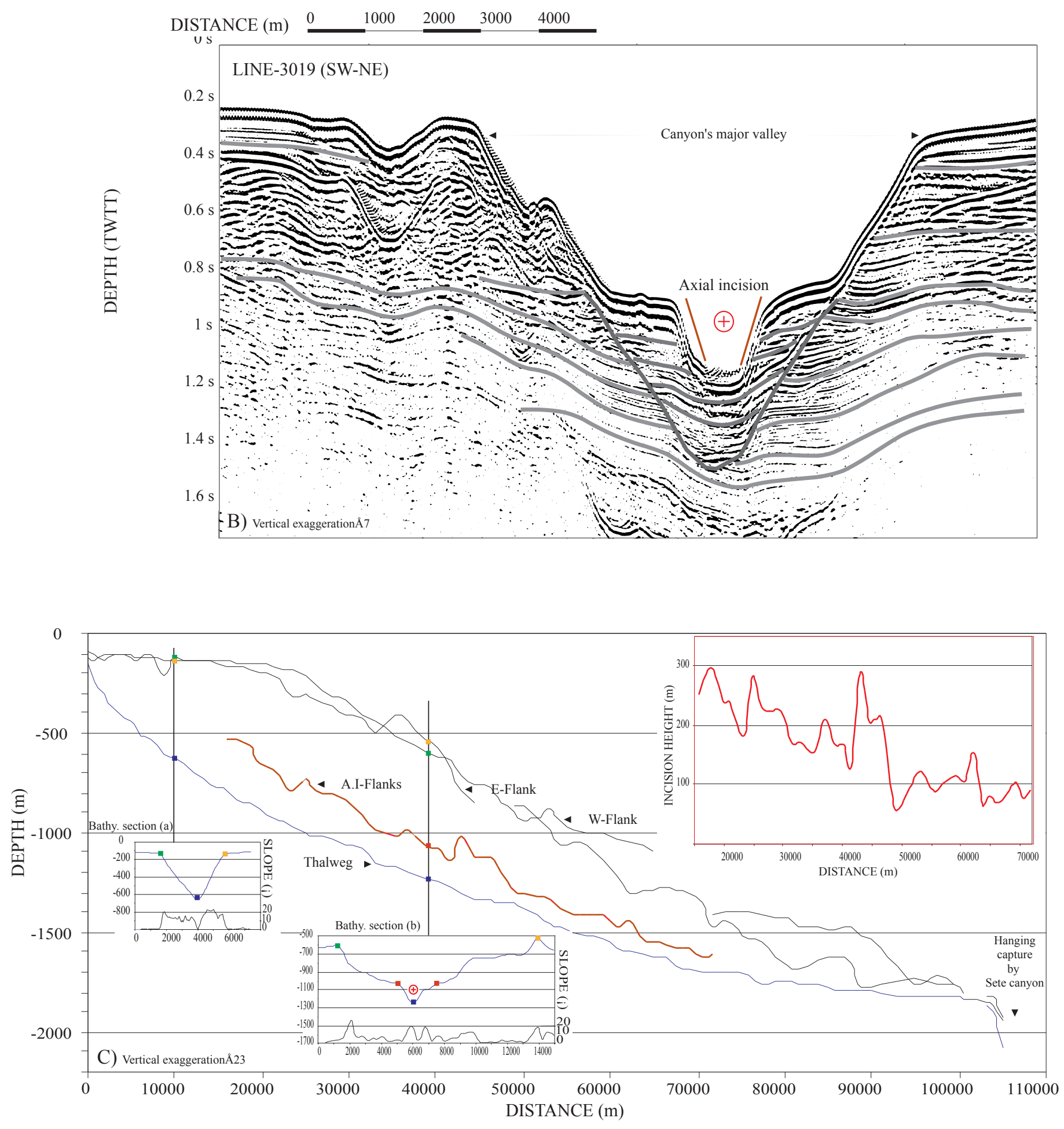

Figure 6-B and 6-C, Baztan et al. 


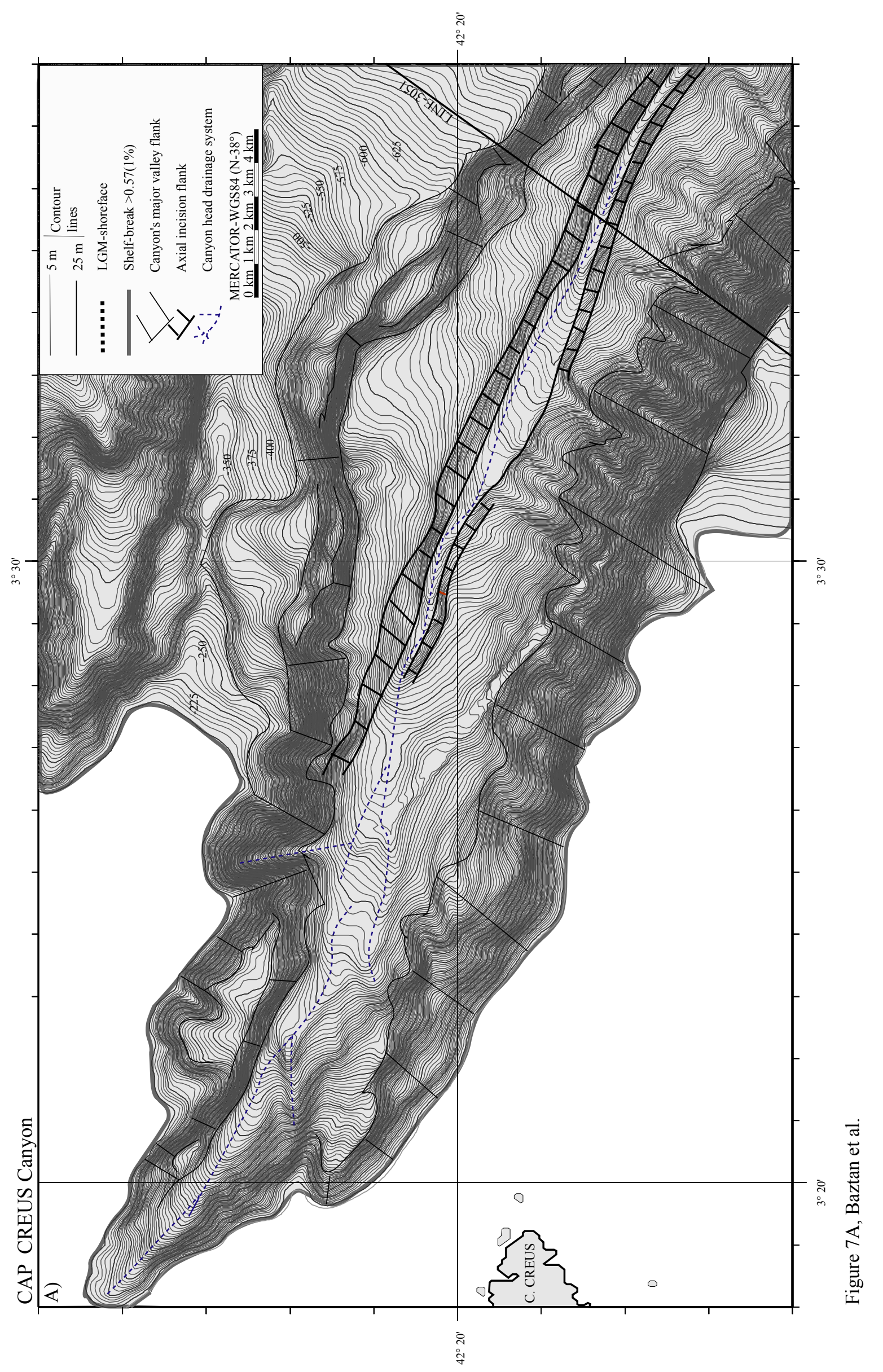



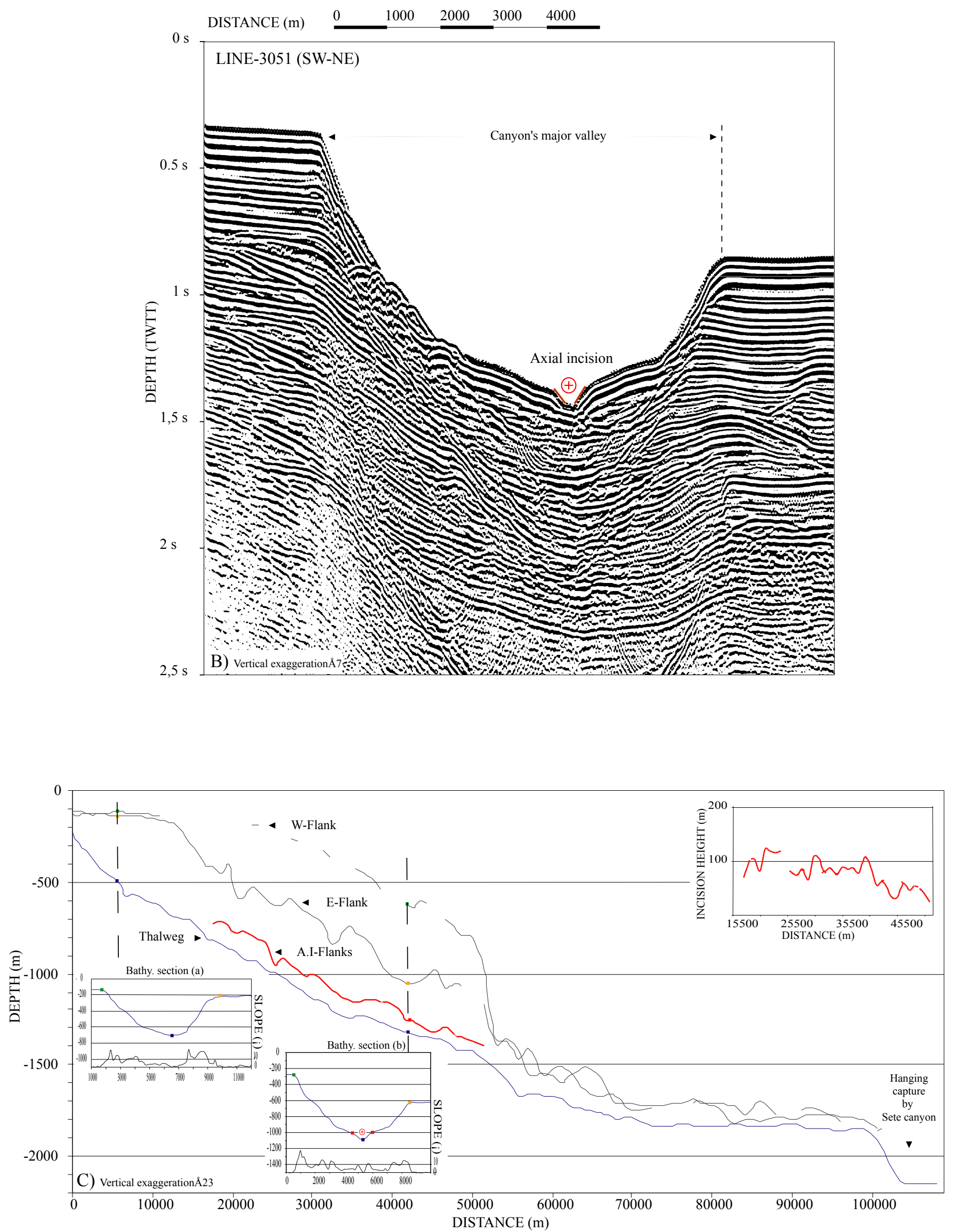

Figure 7-B and 7-C, Baztan et al. 

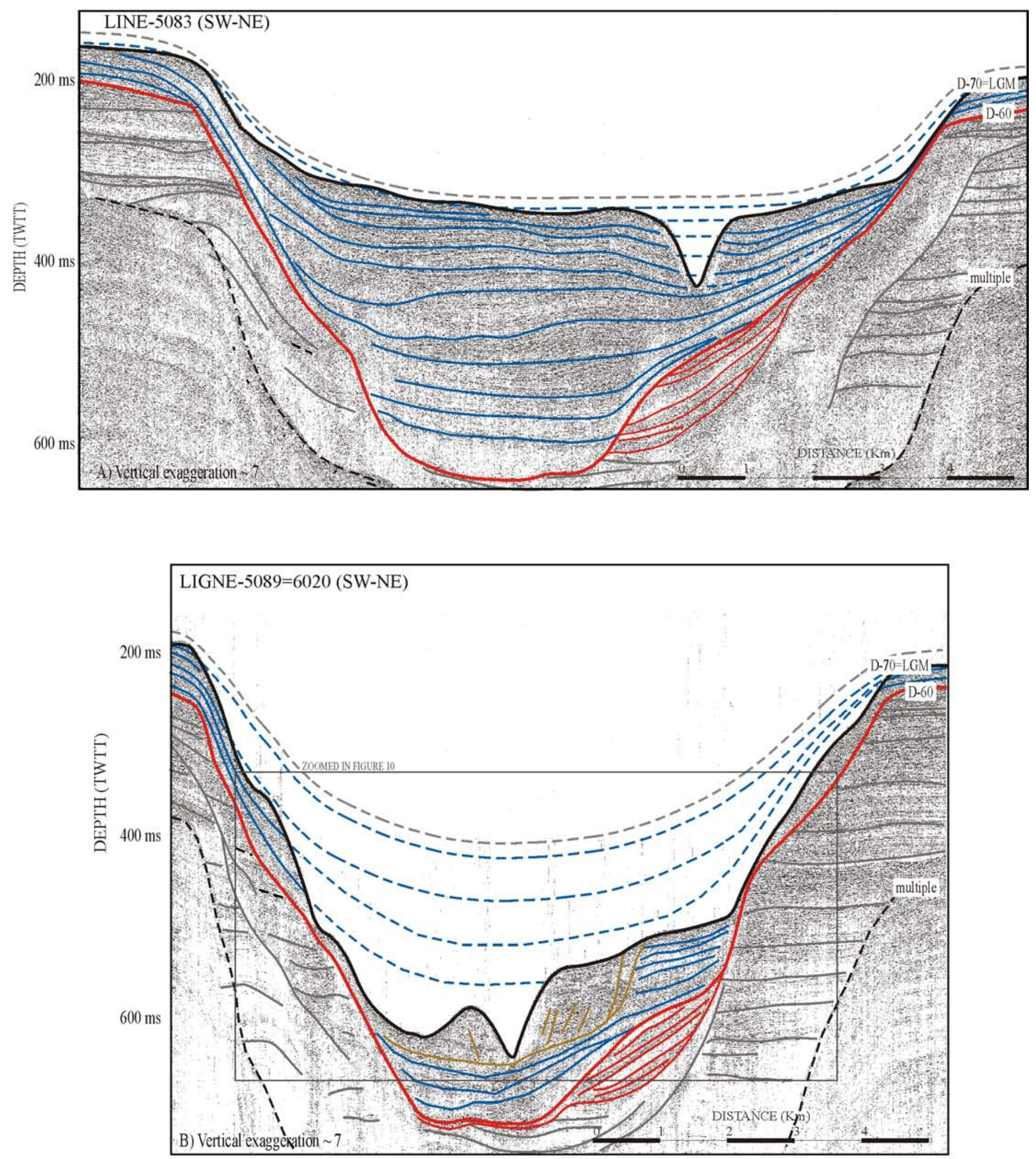

Figure 8, Baztan et al. 

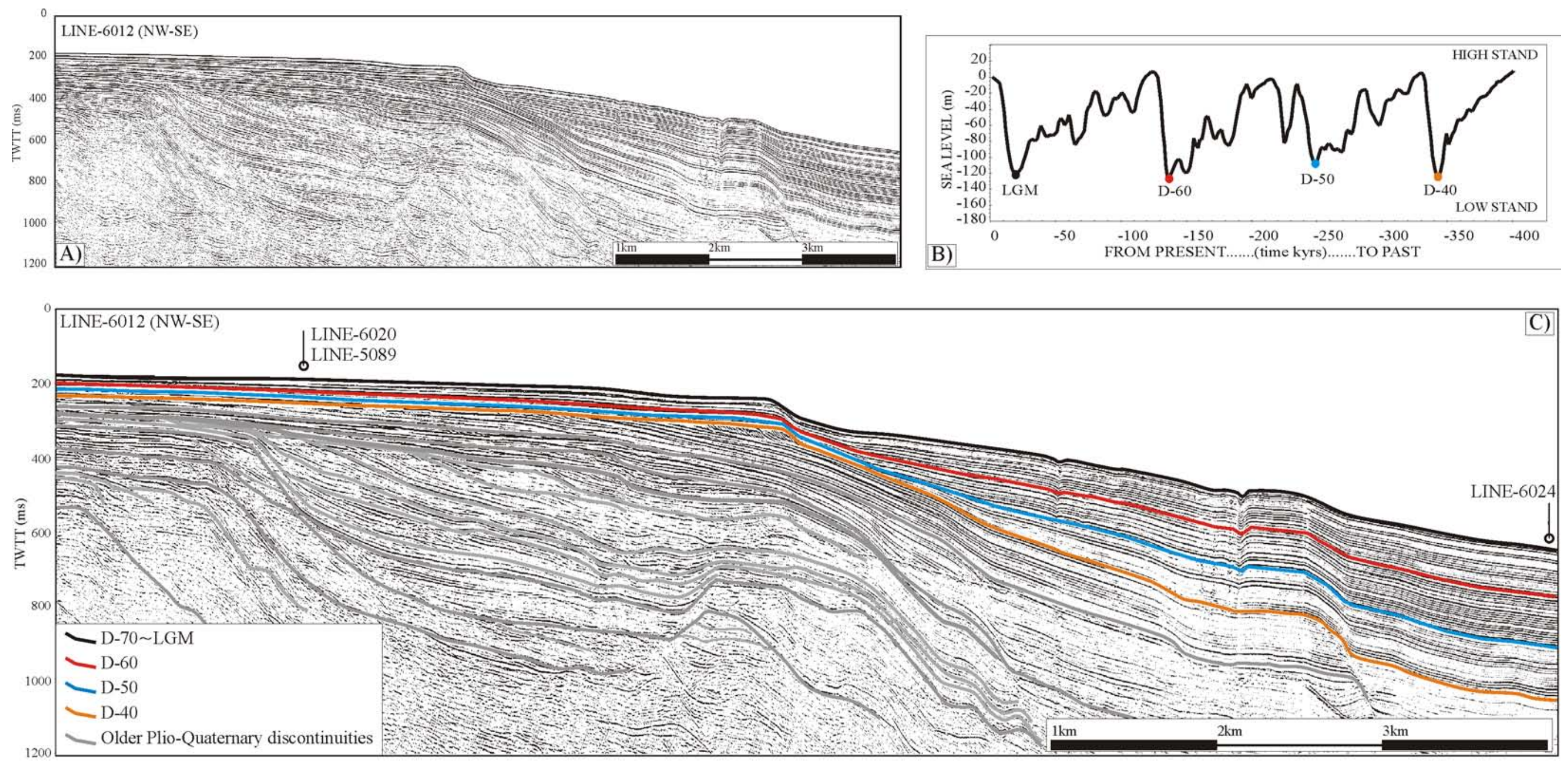

Figure 9, Baztan et al. 

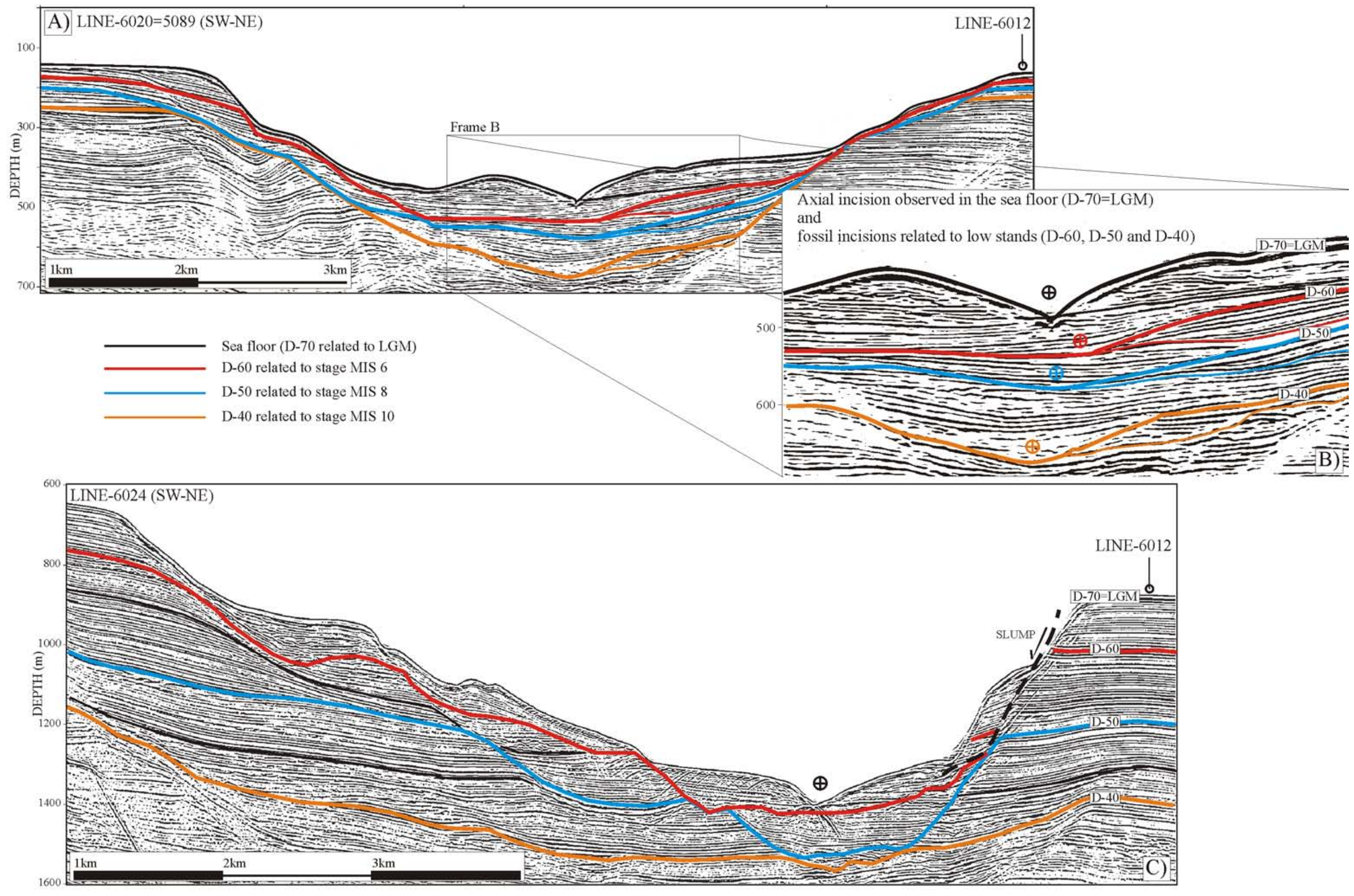

Figure 10, Baztan et al 
DETAIL OF FIGURE 8

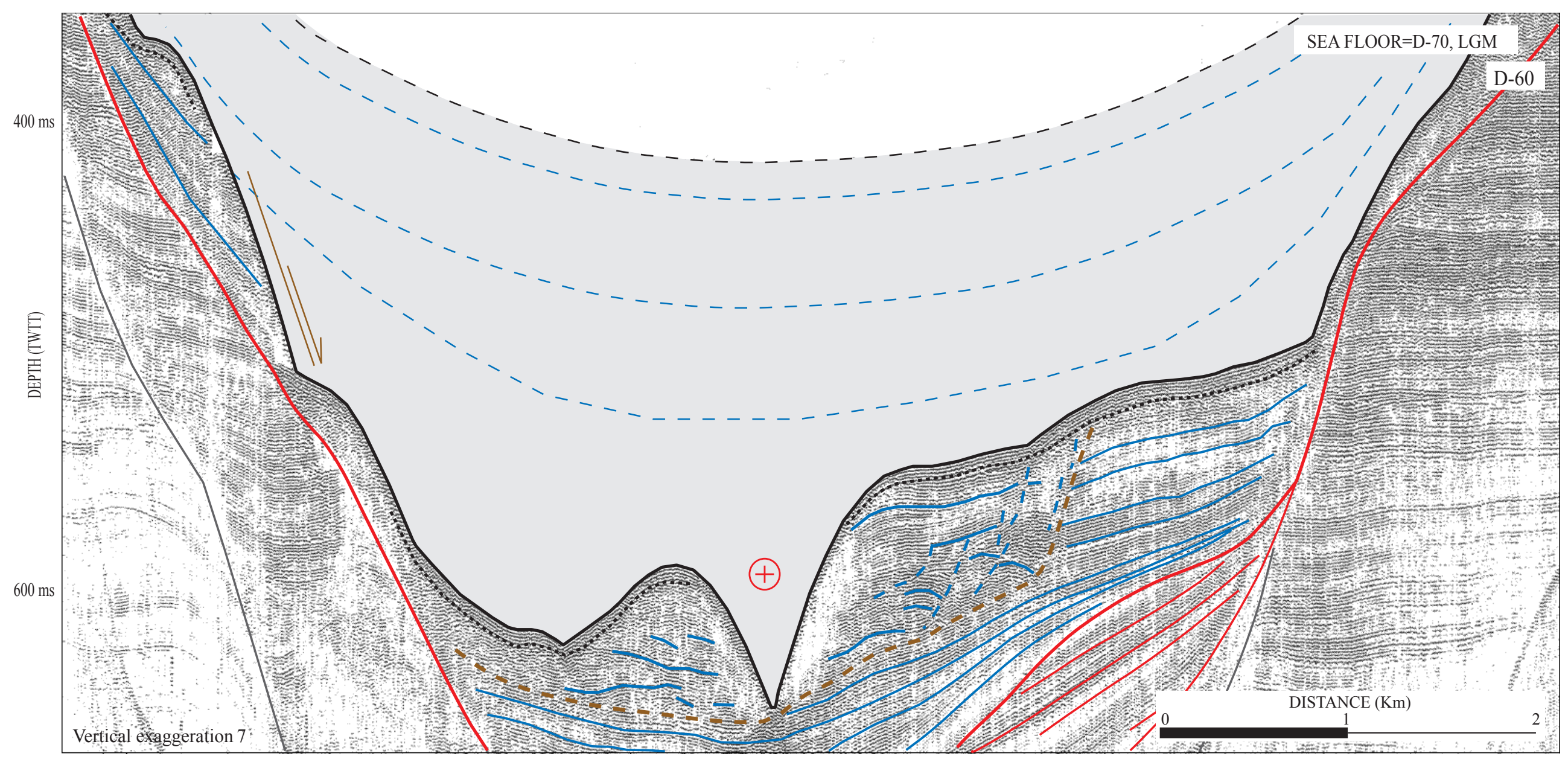

LEGEND

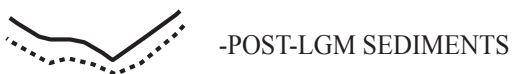

$\oplus \quad$-LGM AXIAL INCISION

-SLUMP SCAR

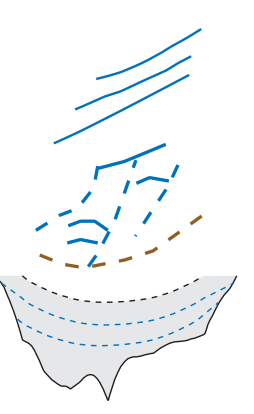

-PRE-LGM (POST D-60) NON PERTURBED SEDIMENTS

-PRE-LGM (POST D-60) PERTURBED SEDIMENTS

POST D-60 ERODED SEDIMENTS

\section{THE ROLE OF THE AXIAL INCISION}

-EROSION

-STRETCH

TRIGGER OF SLUMPS

-DOWNSLOPE TRANSPORT

-DEEPENING AND WIDENING OF THE CANYON'S MAJOR VALLEY

Figure 11, Baztan et al. 
A) $\nabla$

A-1/ INHERITED INCISED STAGE

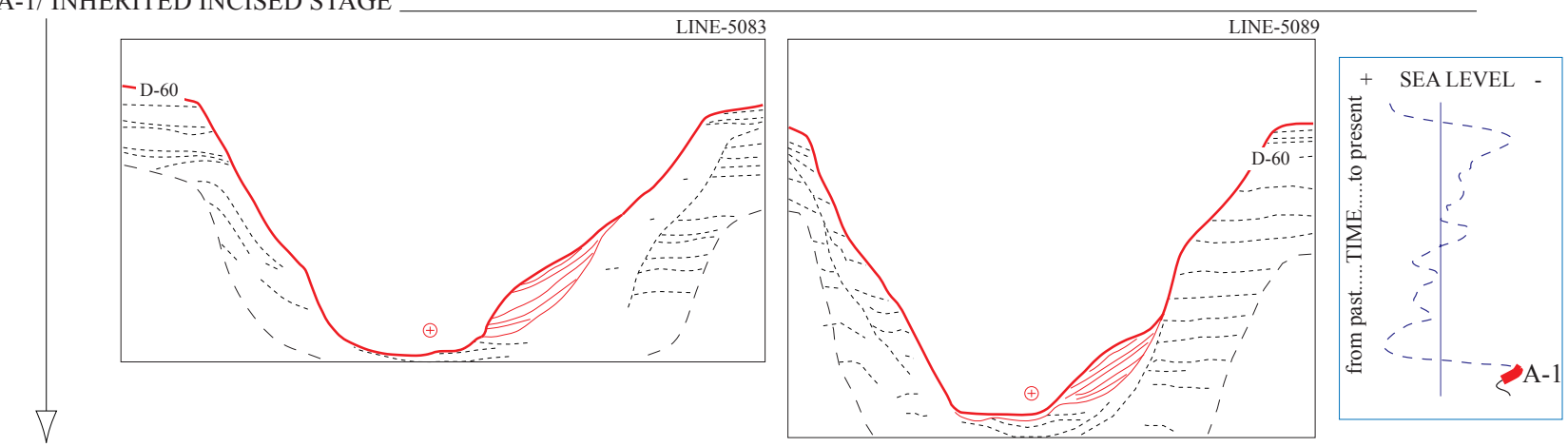

A-2/ EARLY INFILLED STAGE
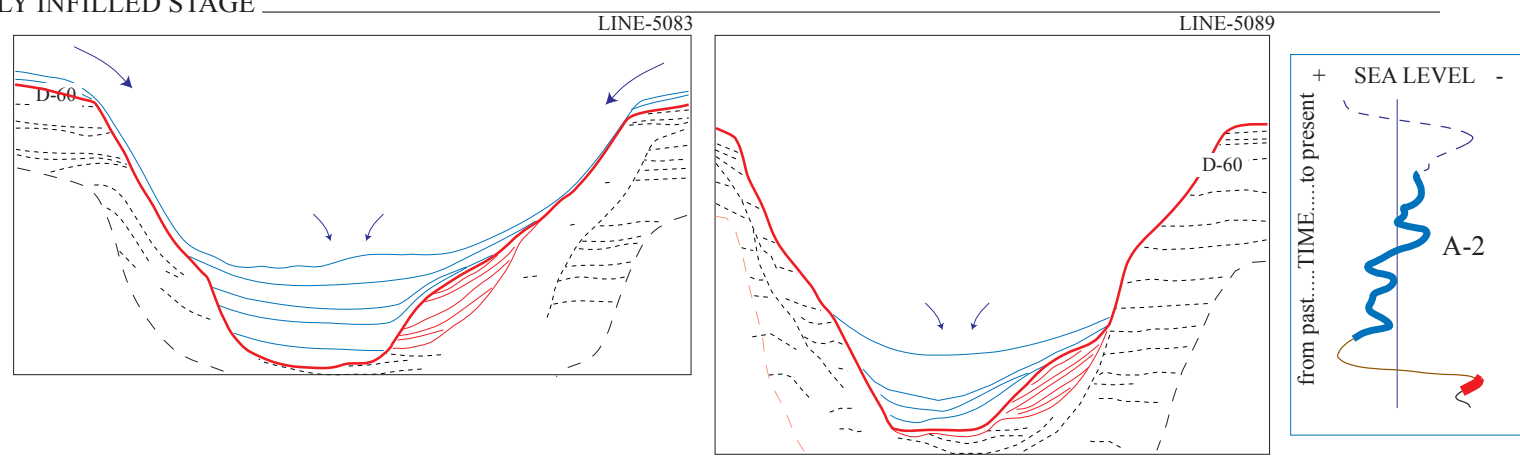

$\triangle \nabla$

A-3/ EARLY INCISED STAGE
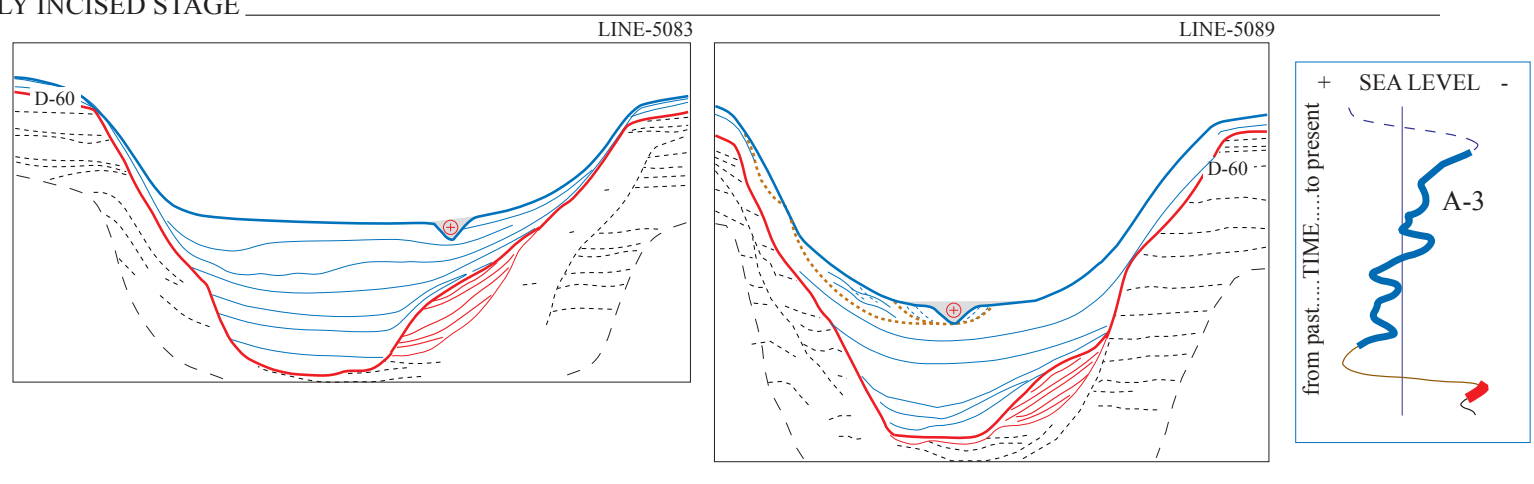

$\nabla$

A-4/ LGM INCISED STAGE
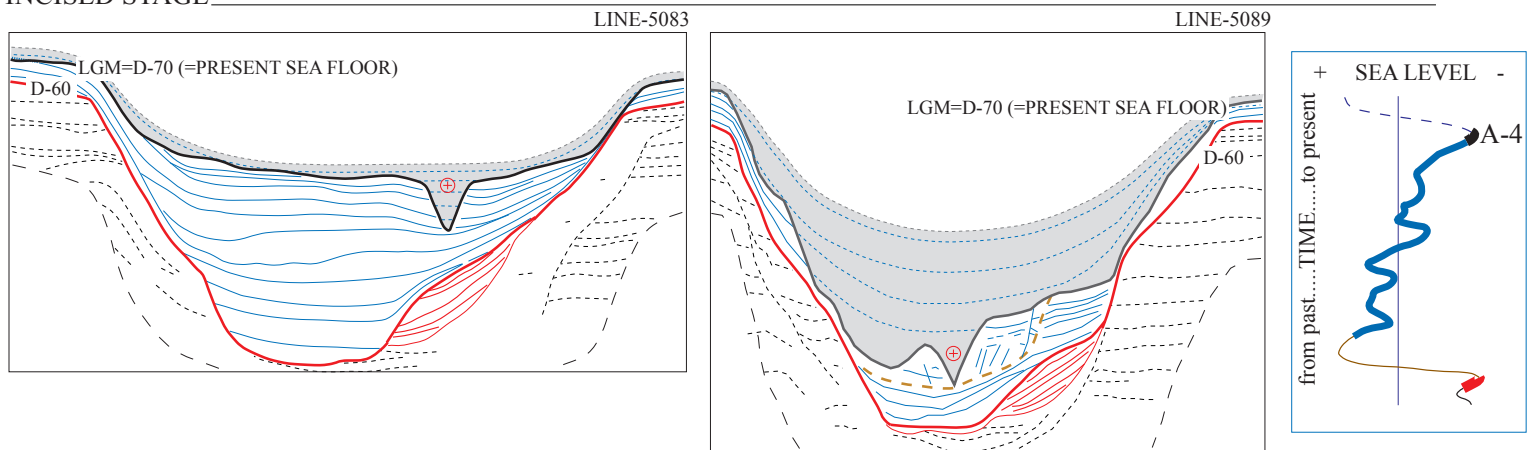

B)

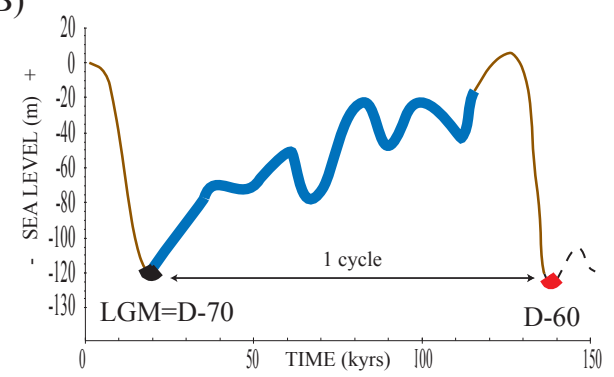

Eroded sediments

Low sediment supply

$\checkmark$ related to transgresions and high sea levels

Highest sediment supply

related to falling

and low sea levels

Lowest sea levels

- related to

axial incision formation

Figure 12, Baztan et al. 

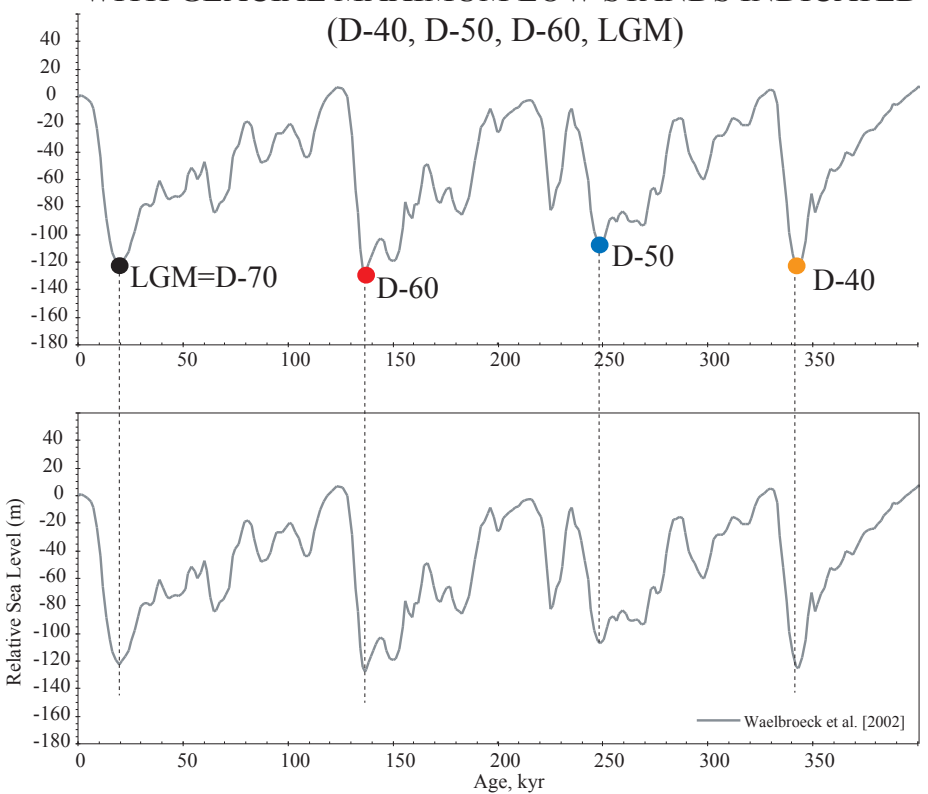

MIDDLE CANYON HISTORY (LINE-6024, FROM FIGURE 11-C)

B)
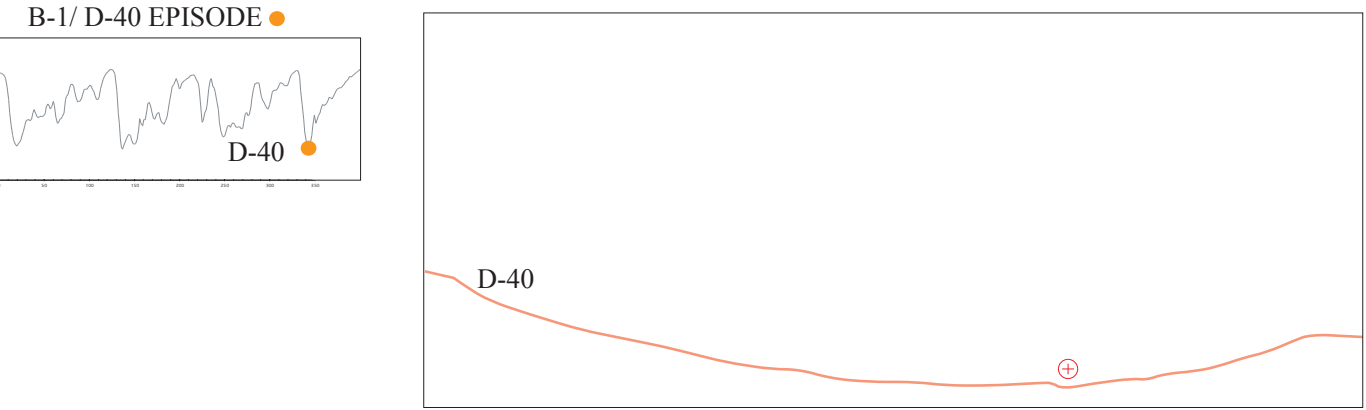

B-2/ D-50 EPISODE
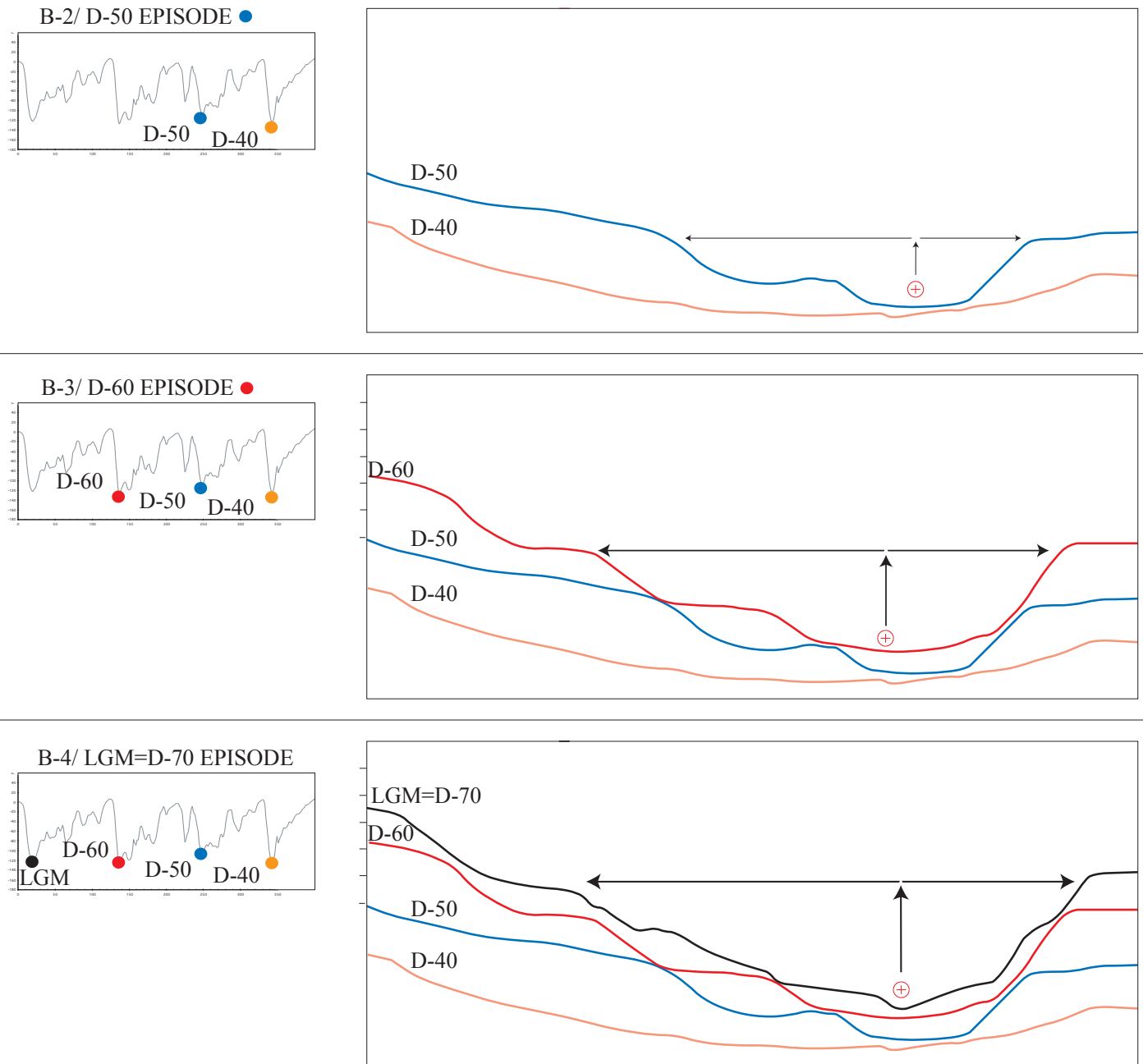

Figure 13, Baztan et al. 


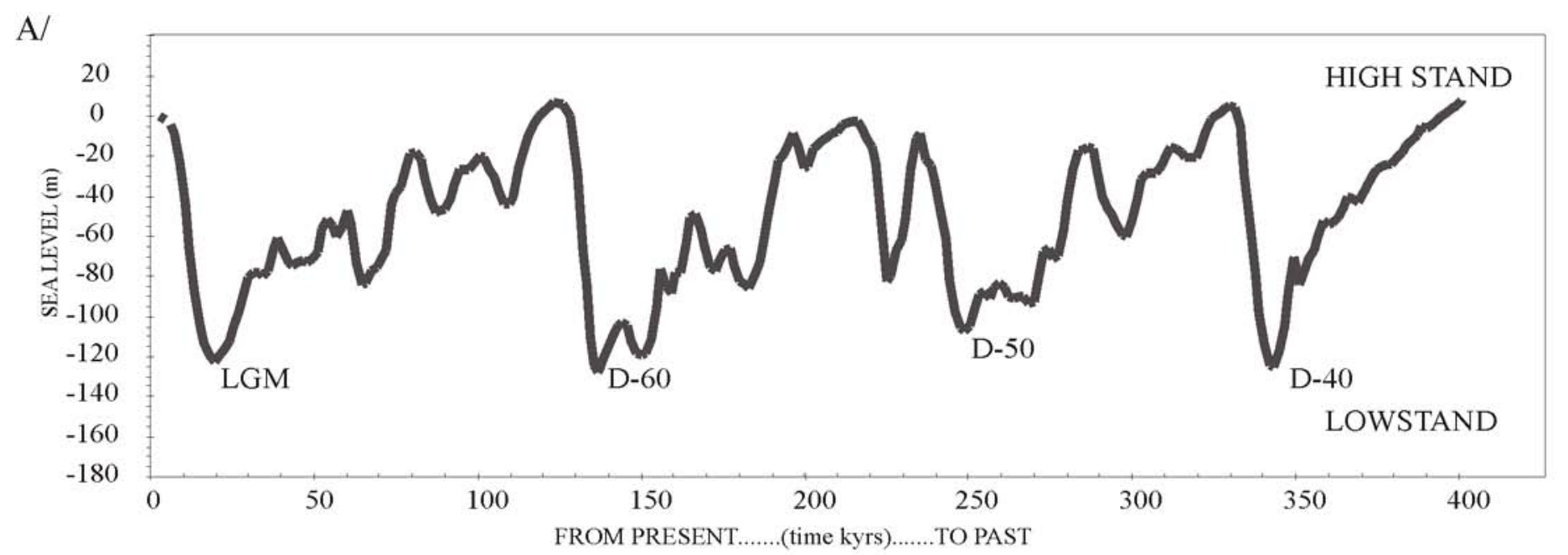

B/

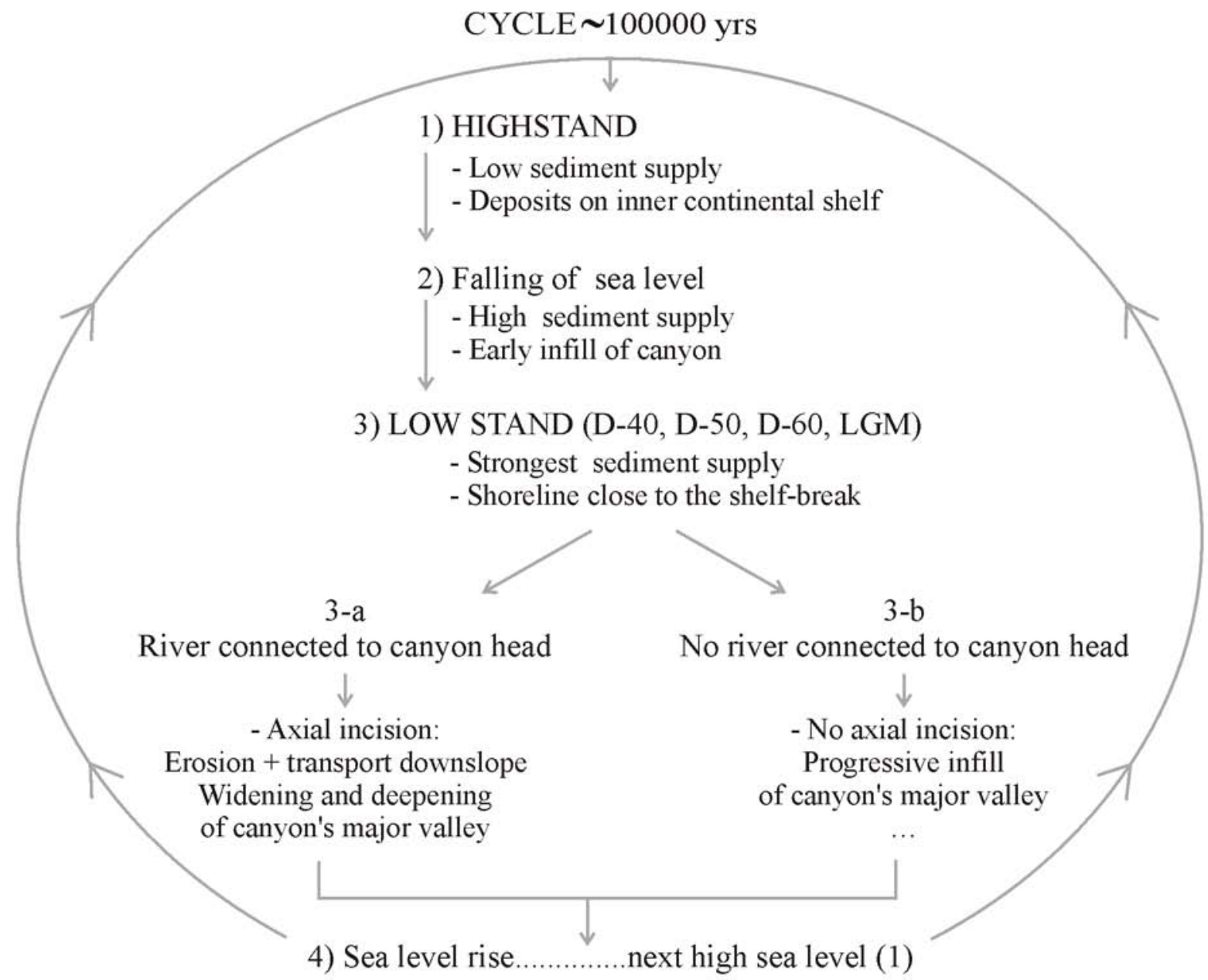

Figure 14, Baztan et al. 